\title{
Nanomaterials-Upconverted Hydroxyapatite for Bone Tissue Engineering and a Platform for Drug Delivery
}

\author{
Nur Akma Abdul Halim ' \\ Mohd Zobir Hussein (D) \\ Mohd Khairuddin Kandar ${ }^{2}$ \\ 'Materials Synthesis and Characterization \\ Laboratory, Institute of Advanced \\ Technology, Seri Kembangan, Selangor \\ Darul Ehsan, 43400, Malaysia; \\ ${ }^{2}$ Department of Orthopedics, Faculty of \\ Medicine and Health Sciences, Universiti \\ Putra Malaysia, Seri Kembangan, Selangor \\ Darul Ehsan, 43400, Malaysia
}

Correspondence: Mohd Zobir Hussein

Email mzobir@upm.edu.my

\begin{abstract}
Hydroxyapatite is a basic mineral that is very important to the human body framework. Recently, synthetic hydroxyapatite (SHA) and its nanocomposites (HANs) are the subject of intense research for bone tissue engineering and drug loading system applications, due to their unique, tailor-made characteristics, as well as their similarities with the bone mineral component in the human body. Although hydroxyapatite has good biocompatibility and osteoconductive characteristics, the poor mechanical strength restricts its use in non-load-bearing applications. Consequently, a rapid increase in reinforcing of other nanomaterials into hydroxyapatite for the formation of HANs could improve the mechanical properties. Most of the research reported on the success of other nanomaterials such as metals, ceramics and natural/synthetic polymers as additions into hydroxyapatite is reviewed. In addition, this review also focuses on the addition of various substances into hydroxyapatite for the formation of various HANs and at the same time to try to minimize the limitations so that various bone tissue engineering and drug loading system applications can be exploited.
\end{abstract}

Keywords: hydroxyapatite, nanocomposites, physicochemical enhancement, bone tissue engineering and drug carrier

\section{Introduction}

Since nanotechnology has emerged across multiple disciplines in recent years, nanomaterials have been gaining interest in biomedical applications especially in the sector of bone tissue engineering. Among various advanced nanomaterials, nanocomposites are composed of numerous nanoscale materials or nanoscale materials reinforced with other types of material. Generally, nanocomposites are formulated and designed in order to amend the properties of certain materials to meet their application. With the urgent need for the clinical development of bone-restoring nanomaterials that are able to mimic and imitate the structure and function of natural bone and are biocompatible to in vivo environment, bone tissue engineering has come out and is flourishing lately. In bone tissue engineering, nanocomposites would focus on rejuvenation of bone tissue instead of bone superseding.

Bone and dentin contain about 45-70 wt.\% of calcium phosphate, $10 \mathrm{wt} . \%$ of water and the remaining part is collagen. ${ }^{82,107}$ The mineralization of calcium phosphate produces hydroxyapatite $\left(\mathrm{Ca}_{5}\left(\mathrm{PO}_{4}\right)_{3} \mathrm{OH}\right)$ in the bone formation process which leads to body enlargement. ${ }^{65,94}$ However, extensive studies on bone mineral proved 
that the mineral in bone contains impure hydroxyapatite due to the presence of minor groups and elements, namely carbonate $\left(\mathrm{CO}_{3}{ }^{2-}\right)$, hydrogen phosphate $\left(\mathrm{HPO}_{4}{ }^{2-}\right)$, sodium $\left(\mathrm{Na}^{+}\right)$and magnesium $\left(\mathrm{Mg}^{2+}\right)$ ions, and trace elements such as strontium $\left(\mathrm{Sr}^{2+}\right)$, potassium $\left(\mathrm{K}^{+}\right)$, chloride $\left(\mathrm{Cl}^{-}\right)$ and fluoride $\left(\mathrm{F}^{-}\right) .^{73}$ These varied elements were utilized in the biochemical reactions of bone metabolism.

Hydroxyapatite is naturally found within the mineral phase of shells, ${ }^{12}$ teeth $^{72}$ and bones in mammalian bodies. $^{29}$ Meanwhile, synthetic hydroxyapatite commonly exists as a white powder. Nonetheless, the elements and characteristics of synthetic hydroxyapatite complement natural hydroxyapatite found in living organisms. The properties of synthetic hydroxyapatite depend on the synthesis technique being implemented, ${ }^{32}$ and hydroxyapatite and hydroxyapatite-reinforced nanomaterials are substantially used in various applications particularly in the biomedical area. Owing to its feature chemically matching with biological calcified tissue, it is extraordinarily biocompatible. ${ }^{48}$ In addition, hydroxyapatite is a bioactive ceramics broadly used as particulate forms or powder in bone repairs, matrix for drug delivery as well as acting as a coatings material for metal prostheses ${ }^{22}$ in order to enhance biological activity.
Hydroxyapatite has high osteoconduction properties, ${ }^{98}$ and it was a material that merged into bone without adverse reaction. Hydroxyapatite is the most stable calcium phosphate ceramic material regarding temperature, $\mathrm{pH}$ and composition of intravascular fluid. ${ }^{49}$

Aside from its advantages, hydroxyapatite has poor mechanical strength which limits its broad application, especially as an implant material. ${ }^{77}$ The mechanical properties of pure hydroxyapatite are in the range of 120-150 $\mathrm{MPa}, 38-300 \mathrm{MPa}$ and 38-250 $\mathrm{MPa}$ for compressive, tensile and bending strength. ${ }^{36}$ Thus, hydroxyapatite-reinforced nanomaterials have been tested and experimented with rigorously, and hydroxyapatite doped versions were used as therapeutic agents to carry the drug locally to specific sites of the body without provoking an immune reaction. From the bone replacement viewpoint, an optimal bone scaffold material should meet the following properties for bone tissue engineering purposes, as illustrated in Figure 1: (1) Biodegradability is an optional feature for every type of scaffold. Scaffold predominantly exhibits degradation properties to give spaces for the growing cell. A man-made scaffold that consists of biodegradable materials will eventually break down into

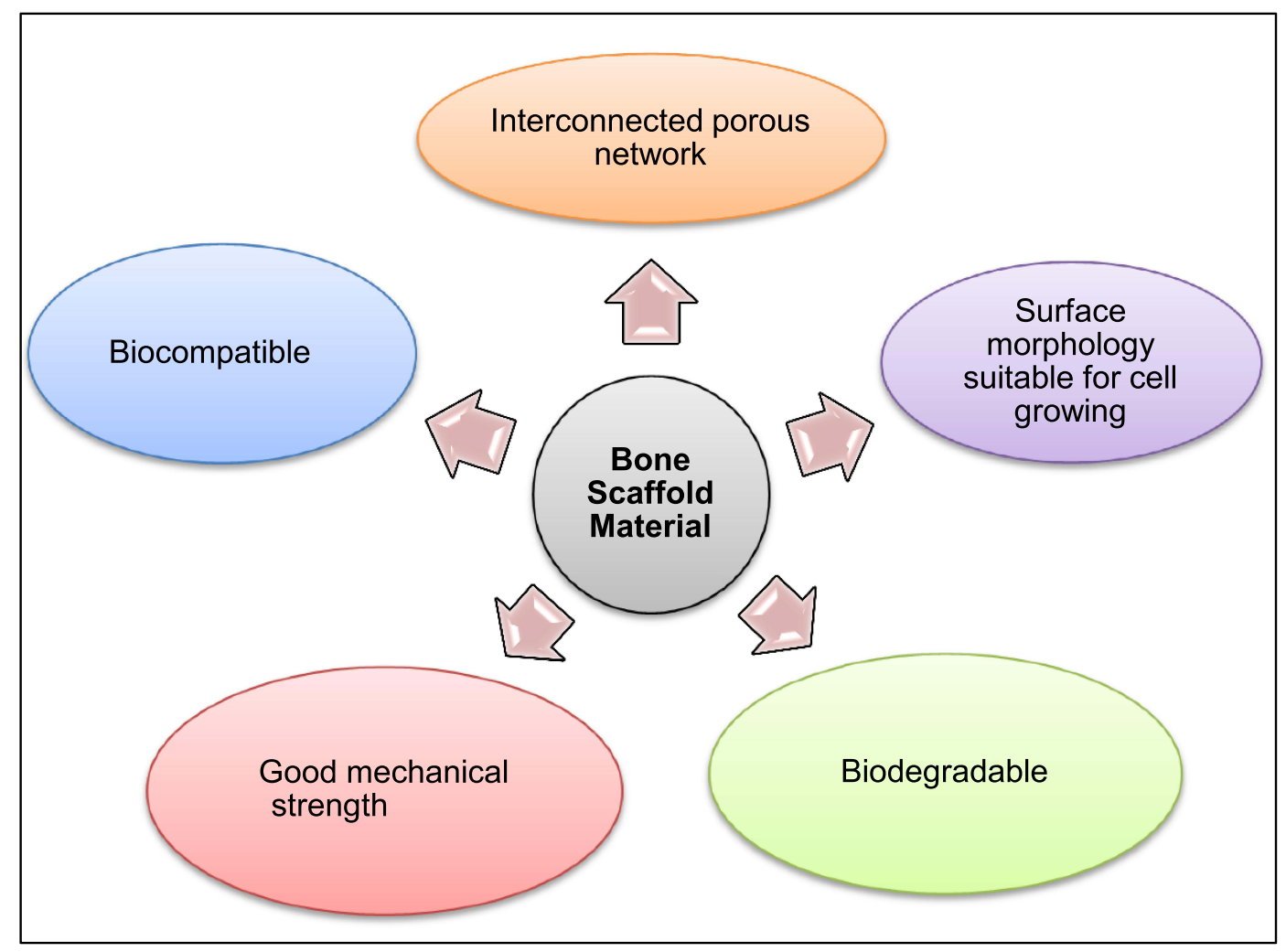

Figure I Some important properties of a bone scaffold. 
small fragments, disseminate and be absorbed in the body at particular phases, and is followed by the growth of new bone tissue. $^{112}$ (2) Biocompatibility of material is pivotal in the scaffold system as it will protect living tissues from harm and toxicity. ${ }^{98}$ The materials used for scaffold development must be able to be incorporated well into the body without showing any harmful effects. (3) Proper mechanical strength of scaffold is a prerequisite to bear the cell ingrowth. The mechanical strength of the scaffold surface will support the adhering cells to grow. Tensile and compressive tests usually were employed to evaluate the mechanical strength of scaffolds in bone tissue engineering. ${ }^{105}$ Besides that, (4) an interconnected porous system is a significant parameter in designing bone scaffold. The pattern of a highly porous interconnected structure with multivariate pore-size distribution will determine the cell recruitment, cell adhesion, ${ }^{17}$ cell proliferation and differentiation, ${ }^{67}$ and gives a passage to gases and nutrient conveyance until the basement for consistent cell growth rate and elimination of waste product along the process. ${ }^{100}$

This present work reviews the appropriate methods employed to produce the optimum amount of products, and the preliminary studies in the biomedical field. In the first section of the review, the authors discuss briefly the synthesis technique of hydroxyapatite nanoparticles and their nanocomposite. Second, the authors revise the application of hydroxyapatite-containing nanocomposites for bone tissue engineering and as a therapeutic agent in drug delivery systems.

\section{Synthesis of Synthesized Hydroxyapatite}

Hydroxyapatite can be synthesized using a chemical precursor. Several methods have been created, for instance, dry method, wet method, thermal method, or a combination of these methods. ${ }^{33}$ Besides that, hydroxyapatite can also be produced from natural sources such as mammalian bones, ${ }^{41}$ egg shells ${ }^{46}$ and plant sources. ${ }^{4,45}$ Each of these methods controls the sizes, chemical composition, crystallinity and morphology of synthesized hydroxyapatite, and those properties influence the biocompatibility, bioactivity, mechanical strength and biological properties. Figure 2 summarizes the several methods used to synthesize the synthetic hydroxyapatite.

\section{Dry Method}

Dry methods are further classified into two different techniques, namely mechanochemical method and solid-state method. ${ }^{83}$ Essentially, the dry method involves the mixing of precursor chemicals which are calcium and phosphate in dry form in order to synthesize hydroxyapatite. ${ }^{24,39}$ The dry method usually does not involve specific and controlled conditions; therefore, dry methods are convenient for the large-scale production of powder. ${ }^{19}$

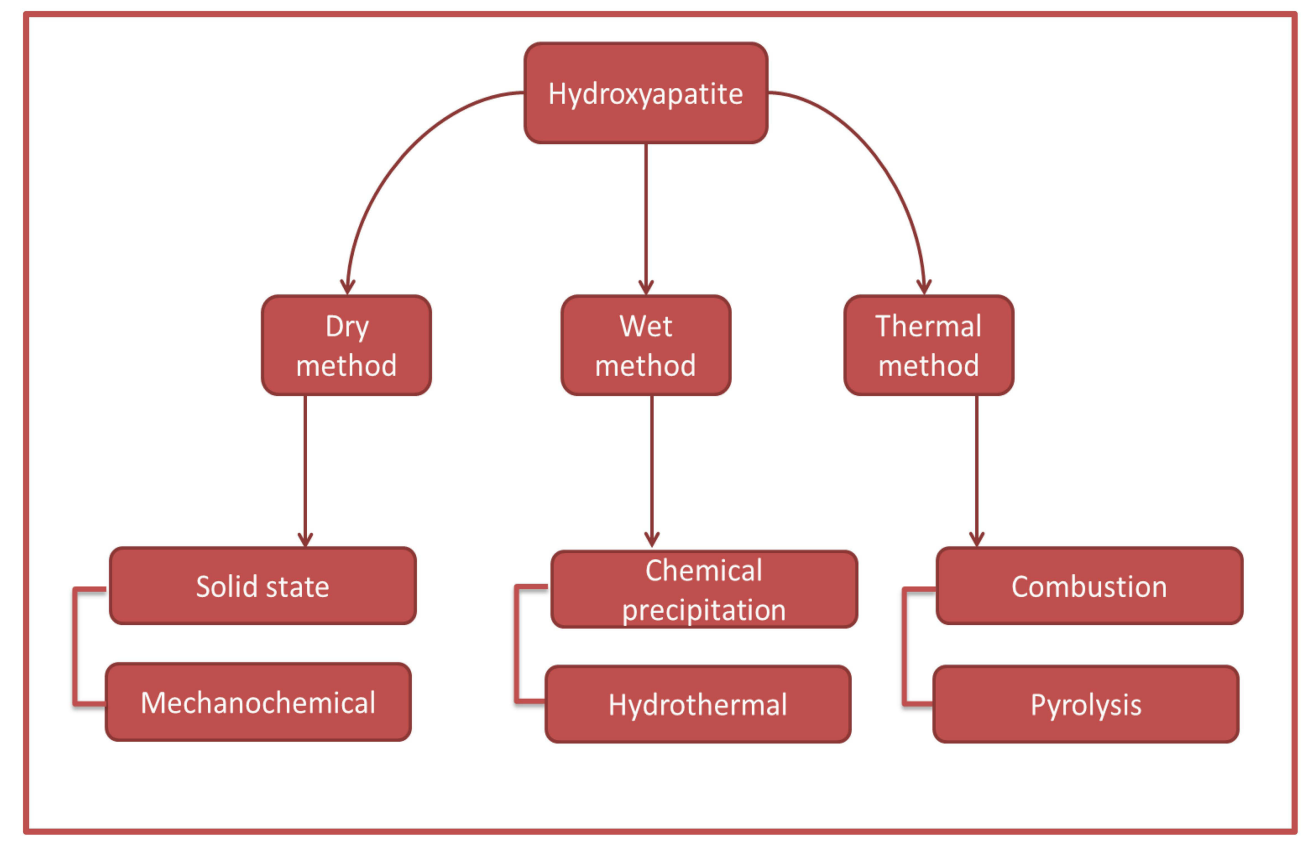

Figure 2 Methods to synthesize the synthetic HA. 


\section{Wet Method}

The synthesis of hydroxyapatite via wet method is in an aqueous solution, and some of this method usually involves the extraction of hydroxyapatite such as chemical precipitation and hydrothermal method. The wet method employs an optimum temperature to synthesizes hydroxyapatite, where the temperature is near to the temperature of the synthesis process of hydroxyapatite in the bone tissue. ${ }^{29}$ Despite the advantages of employing wet methods, such as morphology regulation and control of average size of powder, ${ }^{116}$ the disadvantages, like manifesting low crystallinity due to low temperature during the process, restrict its use in producing synthesized hydroxyapatite. ${ }^{56,100}$

\section{Thermal Method}

In the thermal method, the materials will undergo a decomposition process which is attributed to the high processing temperature. ${ }^{9}$ Throughout all the synthesis methods, namely, combustion and pyrolysis, both methods are rarely employed for synthesizing hydroxyapatite because of difficulty to monitor the processing parameters and secondary aggregates of product. However, thermal methods, notably the combustion technique, were proven to improve antibacterial properties of hydroxyapatite. ${ }^{57}$

\section{Hydroxyapatite Scaffold Containing Nanomaterials as Implant Material in Bone Tissue Engineering: Anti-Bacterial, in vitro and in vivo Studies}

The musculoskeletal system is responsible for supporting the body structure and provides a bone scaffold for the mammalian body. ${ }^{60}$ Technically, the bones of the human skeleton represent anchor sites for muscles, tendons, ligaments and other connective tissues to link tissues and organs and allowing the body's motion. ${ }^{92}$ The natural aptitude of bones is emphasized in the body's unique ability to repair itself via bone regeneration. Nevertheless, bone defects of greater than $50 \%$ of bone loss or approximately $1-2 \mathrm{~cm}$ in length of bone bore that are caused by major injuries do not spontaneously heal without intervention. ${ }^{53}$

Recently, autogenous bone implants (also known as autologous transplantation) were seen as the gold standard in bone regenerative therapies, and generally the bone cells are taken from the patient's own iliac bone.
However, there are many drawbacks of autologous implantation such as unmet supply with great demand, inflammation risk, severe infection and donor site complications among patients. Allograft implants are other therapies used in clinical interventions where the bone cell is taken from other patients. Despite its advantages like providing some growth factors and disclosed osteoinductive properties by activating the signaling pathway to generate new bone cells, limitations like infection between donor and receiver, immune dismissal and even probably also failure restrict their use in bone defect repair.

In the past decades, researchers have shown great interest in engineered bone tissue, as they viewed it as a divergent treatment that potentially suppresses all the issues faced by the current clinical treatments. They suggested that engineered tissue strategies are perceived as the finest techniques since the process is implemented directly to the patient's tissue until the operation is completed. A summary of the integration between hydroxyapatite and other materials to produce nanocomposite scaffold is depicted in Figure 3. Bone tissue engineering is a multidisciplinary field that combines biology and engineering principles and techniques for rejuvenation of bone tissue and involves the evolution of biological substitutes of the autograft and allograft of the bone-implant treatment. Bone tissue structure pertained to a 3D scaffold system to allow them to control the structure together with its mechanical and physical properties. ${ }^{18}$

Many alternatives have been made to diminish the limitation of hydroxyapatite in bone tissue engineering by adjusting nanocomposite structures through the integration of nanomaterials into hydroxyapatite. In this section, the authors aim to focus on the application of hydroxyapatite reinforced with nanomaterials in the bone tissue engineering field by reviewing the antibacterial, in vitro and in vivo studies.

\section{Hydroxyapatite-Metals Nanocomposite Silver}

Silver is a precious metal with potent antibacterial properties, extensively used in biomedical applications, mainly bone tissue regeneration. In a study conducted by Qais et $\mathrm{al}^{84}$ silver nanoparticles were extracted from Murrayakoenigii (L.) (M.koenigii) leaves to study the antibacterial activity of silver nanoparticles (AgNPs). Silver nitrate solution $\left(\mathrm{AgNO}_{3}\right)$ was prepared and added to aliquots of M.koenigii aqueous extracts. After 4 hours of incubation of mixed solution, the solution turns to a dark 


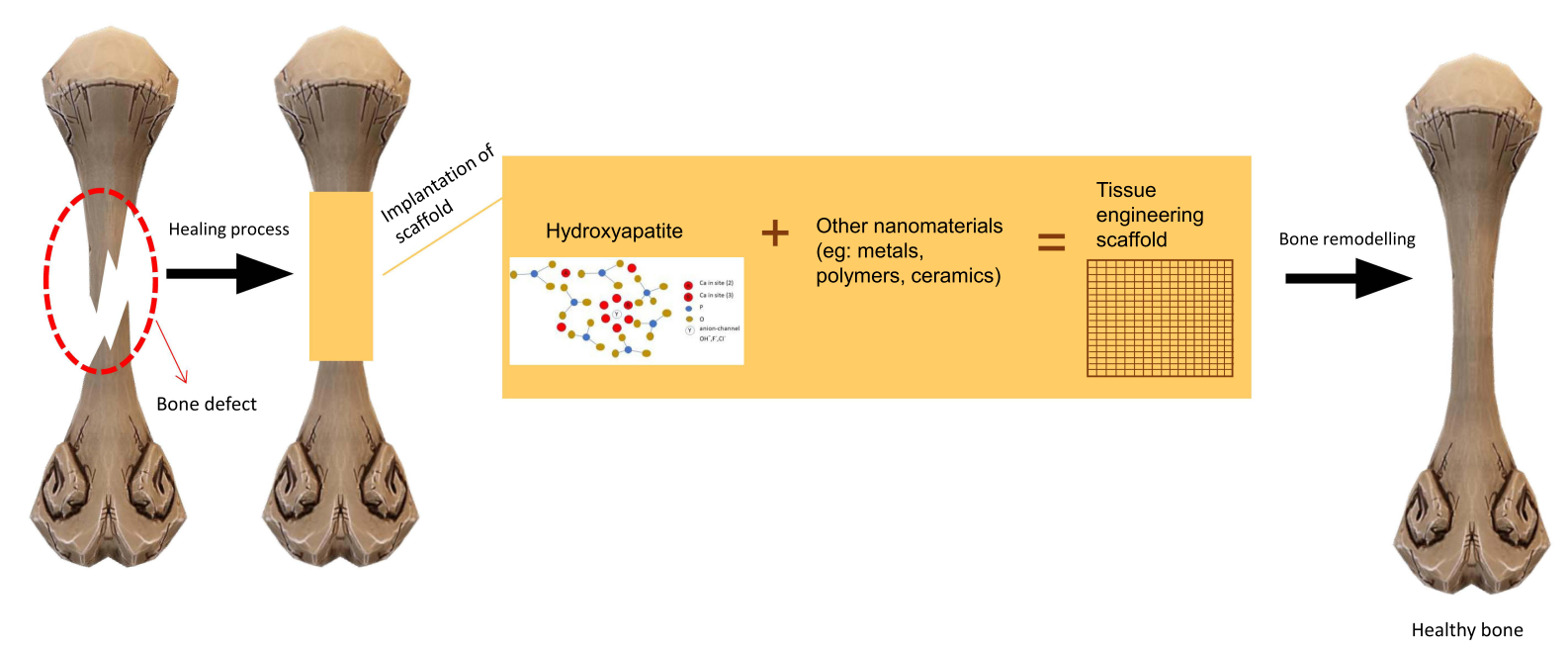

Figure 3 HA reinforced with other materials to form bone scaffold.

brown color indicating the formation of AgNPs. XRD results showed that the average size of MK-AgNPs $(M$. koenigii-silver nanoparticles) was found to be $13.54 \mathrm{~nm}$ which is within the nanosize range. Moreover, in the results of antimicrobial activity against $E$. coli and $S$. aureus, methicillin-susceptible Staphylococcus aureus 2 (MSSA2) showed the most resistance among all bacterium types. MK-AgNPs indicate larger inhibition zones in comparison to $\mathrm{AgNO}_{3}, 16 \mathrm{~mm}$ and $15 \mathrm{~mm}$, respectively. When bacteria are detected in nearby living tissue cells, the silver ion will diffuse out to inhibit the bacteria growth. This is due to the greater surface area of AgNPs which gives a large contact area with the pathogen and makes it easier to destroy. Similarly, Cardozo et $\mathrm{al}^{11}$ found that in the combination of AgNPs with natural antibiotics extracted from the plant, phenazine-1-carboxamine produced a synergic effect against the strains by amending their cell wall structure. The AgNP action mechanism is through the attack of respiratory part and cell separation, which led to microbial inactivation. In addition, the AgNPs not only adsorbed on the cell membrane surface but also inside the pathogen. ${ }^{93}$ It evinced that the AgNPs attach to the cell membrane and infiltrate inside the pathogen as well.

Recent studies done by Khan et $\mathrm{al}^{50}$ had developed a polymeric nanocomposite scaffold composed of arabinoxylan-co-acrylic acid, nano-hydroxyapatite (nHA), nano-aluminum oxide $\left(\mathrm{nAl}_{2} \mathrm{O}_{3}\right)$ and graphene oxide $(\mathrm{GO})$ via free radical polymerization. These nanocomposite (ARX-GO-nHA/n- $\mathrm{Al}_{2} \mathrm{O}_{3}$-AAc) scaffolds were coated with silver nanoparticles (AgNPs) to enhance the antibacterial properties of the scaffold. AA-Ag1, AAAg2 and AA-Ag3 denote each of polymeric nanocomposite scaffolds based on the amount of GO. Anti-bacterial activities were observed against E. coli, P. aeruginosa (Gram-negative) and $S$. aureus (Gram-positive). The AAAg3 nanocomposite, with the highest GO content, had the maximum inhibition zone of antibacterial activities. This can be explained by the sharp GO edges puncturing the membrane by an adsorbing, wrapping and capturing effect and stimulating $\mathrm{Ag}$ ions to the $\mathrm{GO}$ sheets due to the highly negative charge that successfully boosts up antibacterial activities. The oxidation of AgNPs by water/oxygen induce $\mathrm{Ag}^{+}$ions and reactive oxygen species (ROS) to inhibit replication by attacking the deoxyribonucleic acid (DNA). ${ }^{50}$

Besides that, Kumar et $\mathrm{al}^{55}$ employed a freeze-thaw method with a simple modification to synthesize a silver hydroxyapatite (Ag-HA) reinforced gelatin-alginate-PVA cryogel nanocomposite. The XRD results of Ag-HA nanoparticles indicate the reinforcement of $\mathrm{Ag}^{+}$ions into the hydroxyapatite lattice, with increased crystalline properties which are $9.3 \mathrm{~nm}$ and $81.8 \%$ for size of crystallite and crystallinity, respectively. SEM microscopic imaging shows the pores were present in Ag-HA nanoparticles which facilitate cell attachment, as it activates the boneimplant process, hence enhancing bio-integration and stability by assisting in the diffusion of neighboring bone tissue. The porosity of nanocomposite scaffolds is more than $80 \%$ and is suitable for bone tissue engineering because it will allow cell migration and proliferation. Antibacterial assays of Ag-HA nanoparticles and cryogel nanocomposite 
scaffolds were done towards Bacillus spp. and E. coli sp. The inhibition zones were found to be $18 \mathrm{~mm}$ and $22 \mathrm{~mm}$ for Bacillus spp. while they were $12 \mathrm{~mm}$ and $24 \mathrm{~mm}$ for $E$. coli sp., respectively. The authors revealed that when the antigen is detected surrounding cell tissue, Ag ions will be released from Ag-HA nanoparticles, and at the same time the tissue cells adhered to the scaffold surface as the surface has fibroblast morphology. This also proved that the presence of Ag nanoparticles does not affect the compatibility and toxicity towards the tissue cell and the aptitude for cell adhesion and growth. The Ag-HA nanoparticles are more efficient to prevent the growth of bacteria without altering the biocompatibility properties of hydroxyapatite compared to native hydroxyapatite. Additionally, the concentration of $\mathrm{Ag}$ nanoparticles influences the degree of bacterial activity inhibition. ${ }^{37}$ The higher the concentration of $\mathrm{Ag}$ nanoparticles in the nanocomposite scaffold, the greater the efficiency of bacterial growth inhibition. Nevertheless, it is important to control the concentration of silver in the scaffolds because an excessive amount of silver can lead to inhibition of bone tissue growth and increase toxicity in the human body. ${ }^{44,87}$

\section{Zinc}

Zinc plays an important role in the human body. The dissemination of zinc in the human body is nearly $57 \%$ in muscle, $29 \%$ in bone, $6 \%$ in the skin, $5 \%$ in the liver, $1.5 \%$ in the brain and $0.1 \%$ in blood plasma. ${ }^{80}$ Zinc is involved in several enzyme activities such as protein synthesizing and deoxyribonucleic acid (DNA) and ribonucleic acid (RNA) activation via zinc finger protein. In recent times, zinc as a trace element has been experimented with and developed for cardiovascular and orthopedic applications due to its favorable properties like mechanical durability, biocompatibility, biodegradability and use as an adequate antimicrobial agent. ${ }^{96}$ Furthermore, from a bone formation standpoint, zinc is crucial in stimulating osteoblast cell formation, ${ }^{13}$ protecting bone from breakdown, and it reduces the toxic effect from other metals, especially cadmium. ${ }^{15}$ As noted by Qi et al, ${ }^{85}$ when streptozotocin-induced diabetic rats were treated with $0.25 \mathrm{mg}$ / $\mathrm{kg} / \mathrm{d}$ zinc sulfate by daily gavage feeding for 8 weeks, this resulted in thicker trabecular bone, and bone mineral density (BMD) and femoral bone significantly improved, although the rats were still diagnosed as hyperglycemic.

Ofudje et al employed hydroxyapatite-containing zinc (HA-Zn) nanocomposites via chemical co-precipitation method for bone regeneration application. ${ }^{81}$ The result revealed that the higher the zinc content in the HA-Zn nanocomposite, the lower the crystallinity of apatite. The deformity existed in the hydroxyapatite lattice structure as zinc ions were introduced into hydroxyapatite and caused a dwindling to the structure of hydroxyapatite. In spite of that, the incorporation of $\mathrm{Zn}$ into hydroxyapatite requires sintering at high temperatures to substitute calcium ion (Ca) and fill the vacancy in the lattice site. SEM analyses show the round shape and needle-like structure of hydroxyapatite nanocrystals with lengths within the range of 15$35 \mathrm{~nm}$ and width $4-12 \mathrm{~nm}$. It is worth noting that the hydroxyapatite nanoparticle size is vital for the implant material in order to ensure contact reaction and stability of the natural/artificial bone attachment. Further, the morphologies of $\mathrm{HA}-\mathrm{Zn}$ nanocomposite demonstrate the presence of interconnected porosity in the scaffold structure, ${ }^{81}$ which is beneficial in stimulating bone formation as it is a prerequisite for bone tissue engineering. Anyhow, 20\% of Zn-doped hydroxyapatite shows the highest inhibition area, while no inhibition area was observed when the bacteria were treated with pure hydroxyapatite, indicating that hydroxyapatite lacks antimicrobial activity. As mentioned, the crystallinity of hydroxyapatite decreased when $20 \%$ of zinc was inserted and caused the enlargement of apatite surface area, thus forcing microorganisms to attach to the apatite surface, and resulting in cell death. Hydroxyapatite tends to bind with functional groups (imidazole, thiol, carboxyl and amino groups) on the pathogen surface due to the protein-type membrane, and eventually altering the surface morphology of the pathogen. ${ }^{101}$

Recently, a study on the osteogenesis behavior of citrate zinc hydroxyapatite nanocomposite for bone tissue engineering was done by Fernandes et al. ${ }^{28} \mathrm{~A}$ one-step hydrothermal technique was utilized in synthesizing citrate zinc hydroxyapatite (cit-Zn-HA) nanocomposite. The presence of zinc in cit-Zn-HA nanocomposite reduced the $\mathrm{Ca} /$ $\mathrm{P}$ atomic ratio to 1.55 from the normal level of 1.67 , but the ratio of cit-HA was near the normal ratio, which is found to be 1.66. These results can straightforwardly be related to the $\mathrm{Ca}(\mathrm{Cit})^{-}$ions that could be replaced by $\mathrm{Zn}$ citrate ions, so the amount of $\mathrm{Ca}$ decreases upon the addition of $\mathrm{Zn}$. As such, the $\mathrm{Ca}$ ion $(0.99 \AA)$ has a larger ionic radius compared to $\mathrm{Zn}(0.74 \AA)$. Significant depletion was observed in nanoparticle length along the longest axis upon the presence of zinc, resulting in the decrease in length of hydroxyapatite nanoparticles. This result is in agreement with previous studies, ${ }^{81}$ evidencing that the 
incorporation of zinc with hydroxyapatite shortens the length of nanoparticles and impacts the crystallinity and morphology as well. Other than that, the osteogenic response of human bone marrow-derived stromal cells (hBMSCs) indicates good cell viability without apoptotic events and elongated F-actin-stained cells with the conspicuous nucleus as well as the cell-to-cell connection. Overall, the cell proliferation results presented more exuberant, with highest ALP activity and obvious calcium phosphate deposits when exposed to cit-Zn-HA compared to cit-HA and Zn-HA. These results are demonstrating that the osteogenic and mineralization activities are perhaps due to a synergistic effect as a result of zinc and citrate incorporation into HA.

\section{Copper}

Among various metals employed for bone replacement application, copper $(\mathrm{Cu})$ is the most often-used metal due to its significant role in the human body and antibacterial properties. $\mathrm{Cu}$ can destroy bacteria through lipid peroxidation, oxidation of protein, DNA disruption and promoting reactive oxygen species (ROS). ${ }^{69}$ Essentially, the antibacterial activities of copper are known to be more efficient in high temperatures and high relative humidity within hours. ${ }^{31,34}$ In one study viable endospores in Clostridium difficile spp. were completely inactivated within $24 \mathrm{~h}$ to $48 \mathrm{~h}$ on a copper surface. ${ }^{111}$ Another study was conducted by Sahithi et $\mathrm{al}^{91}$ who investigated the antibacterial activity of hydroxyapatite and hydroxyapatite-doped $\mathrm{Cu}$ nanocomposite against Grampositive strain (S. aureus) and Gram-negative strain (E. coli).
Staphylococcus aureus (S. aureus) is a type of pathogen that is commonly associated with bone device-related infections and also antibiotic resistance, while Escherichia coli (E. coli) tends to decrease osteoblast cell viability during the osteogenesis process of bone formation. ${ }^{21,68,102}$ Hydroxyapatite behaved like an inert material as it does not support or prevent bacteria growth in the same way as the control. But, when hydroxyapatite is doped with $\mathrm{Cu}$, the optical density value indicates antibacterial activity events in both Gram-positive and Gram-negative bacteria. Also, the MTT assay proved that these nanomaterials combinations are safe to be used for bone implants since the cell viability remains unchanged. Contrary to the results obtained by Nam et al, ${ }^{76}$ pure hydroxyapatite and CuHA nanocomposite show good antibacterial activity. The addition of $\mathrm{Cu}$ solely improved the inhibition of $E$. coli and $S$. aureus activity compared to pure hydroxyapatite. As the concentration of $\mathrm{Cu}$ increased in the hydroxyapatite nanocomposite, the antibacterial ratio increased from $22 \%$ to $89 \%$ and $29 \%$ to $98 \%$ against $E$. coli and $S$. aureus, respectively. The $\mathrm{Cu}$ ions in the hydroxyapatite nanocomposite will tie up hydroxyapatite to the cell wall and disrupt the bacterial cellular system. ${ }^{101}$ Nevertheless, a different type of bacterium will have distinct sensitivity depending on their membrane structure, as shown in Figure 4A and B. The Gram-positive bacteria are more attracted to $\mathrm{Cu}$ ions due to the negatively charged surface of lipoteichoic and teichuronic acid inside the porous layer of peptidoglycan. The copper ion will be attached to the outer layer of Gram-positive bacteria by electrostatic forces, resulting in cell damage by protein denaturation and destruction of
A

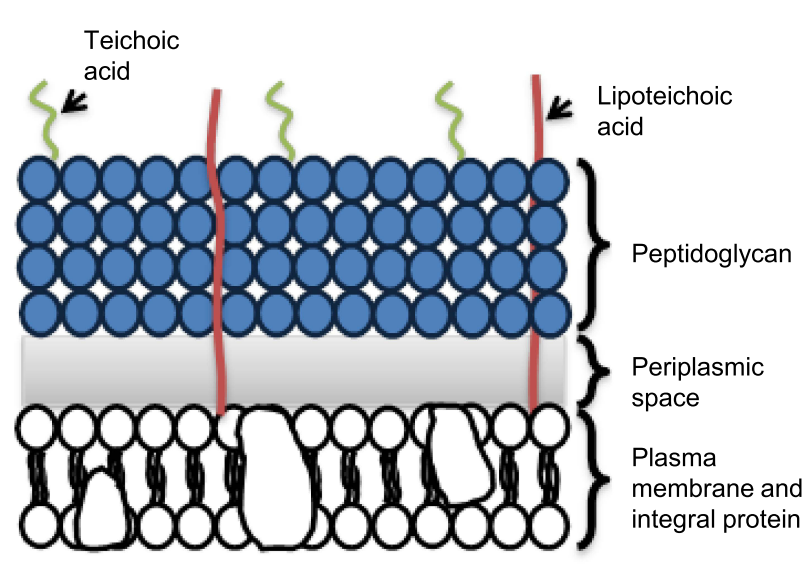

B

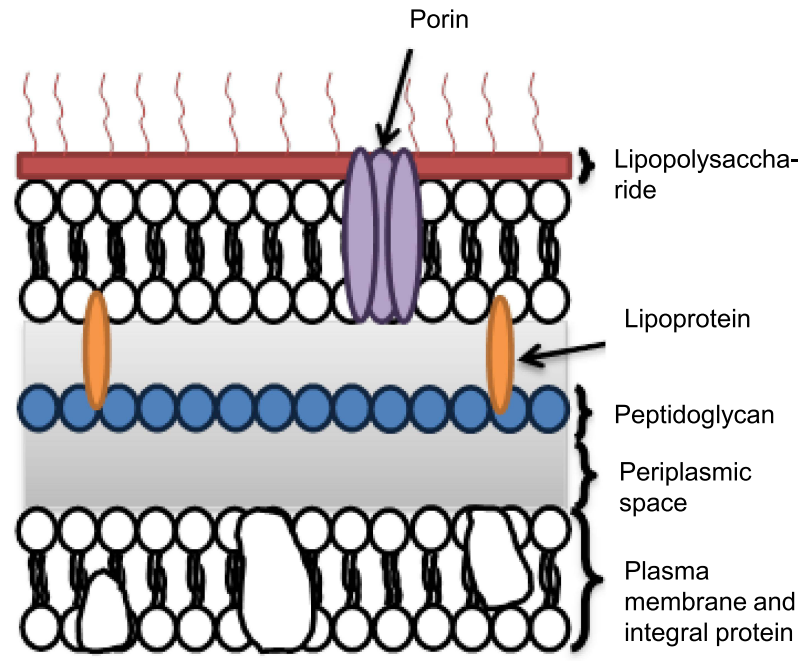

Figure 4 Structure of (A) Gram-positive and (B) Gram-negative bacteria. 
the cell membrane. ${ }^{5}$ On the other hand, Gram-negative bacteria have a compact outer member structure that will act as a barrier to prevent the penetration of certain compounds, especially high molecular weight compounds, thus making them less attractive to metal ions. ${ }^{5}$ Although the high content of $\mathrm{Cu}$ indicates good antimicrobial activity, it was evidenced that it also increases the apoptosis event which is forbidden for bone tissue engineering. ${ }^{2}$ Therefore, it is mandatory to choose the optimum concentration of $\mathrm{Cu}$ content in the nanocomposite scaffold in order to provide the finest living environment for cells.

Aside from topical antibacterial agents, $\mathrm{Cu}$ is predominant in providing cell proliferation of osteoblast assisting in cell differentiation, ${ }^{2}$ and it is important in promoting angiogenesis fit for bone regeneration. ${ }^{5}$ The combination of $\mathrm{Cu}$ and hydroxyapatite has been shown to improve hydroxyapatite properties as well as facilitate cell growth for bone regeneration. For instance, $\mathrm{Ai}$ et $\mathrm{al}^{2}$ investigated hydroxyapatite scaffold doping with $\mathrm{Cu}$ for bone tissue engineering. The CCK-8 test was done using different $\mathrm{Cu}$ ratios, namely $1 \mathrm{CuHA}, 5 \mathrm{CuHA}, 10 \mathrm{CuHA}$ and $15 \mathrm{CuHA}$, to observe cell proliferation of bone mesenchymal cells (BMSCs). They noticed that 1CuHA promotes cell proliferation and also 5CuHA maintained a good growth state of BMSCs. In contrast, 10CuHA and 15CuHA showed high inhibition rates after inoculation for 7 days. Similarly, Guo et $\mathrm{al}^{35}$ found that at low $\mathrm{Cu}$ content, copper-doped calcium polyphosphate (CCAP) nanocomposite scaffolds exhibited good cell proliferation of human osteoblast while high $\mathrm{Cu}$ content nanocomposites impeded the cell proliferation. Thus, when the $\mathrm{Cu}$ ions surpass the optimal limit, this leads to significant toxicity effects on cells ${ }^{89}$ and increases the free radical species production that causes neurodegenerative diseases. ${ }^{38}$

In addition, SEM micrographs ${ }^{2}$ showed the presence of interconnected pores in CuHA scaffolds that is convenient for cell migration, cell proliferation and vascularization to facilitate cell growth. A study was done by Stanic et al ${ }^{101}$ on the cytotoxicity of HA-Cu nanocomposites towards living cells by testing rat primary osteoprogenitor cells and demonstrated that the cell viability remained unchanged, and it confirmed that copper ion is safe to be used with hydroxyapatite for bone tissue engineering. Nonetheless, the addition of copper ions will affect the crystallinity of hydroxyapatite, but it can be avoided by sintering and aging processes during the preparation steps. Thus, the hydroxyapatite doping with $\mathrm{Cu}$ of nanocomposite scaffolds is applicable in their use as a nanomaterial implant for bone tissue engineering at the optimum ratio of $\mathrm{Cu}$ content and in controlled conditions.

\section{Hydroxyapatite-Polymer Nanocomposite Chitosan}

Owing to features like biodegradability producing degradable products, high biocompatibility and commercial availability, much attention has been paid to the chitosan application in both research and development for bone filler. ${ }^{89}$ Chitosan is a type of natural polymer derived from the deacetylation of chitin treated with alkaline substances. It has a structure composed of plentiful reactive amino and hydroxyl groups as illustrated in Figure $5 .^{26}$ This reactive amino group is very useful to induce a cellular response in scaffolds formulation as it improves surface chemistry and wettability and reduces hydrophobicity of scaffolds surface in order to initiate cell attachment, spreading and proliferation. ${ }^{110}$ The degradation of chitosan in the in vivo environment generates small, nontoxic and readily absorbed molecules of amino and polysaccharides. ${ }^{95}$ To tailor characteristics such as solubility, chemical reactivity and biological activity to diversify its application in bone tissue engineering, chitosan needs some modification. The incorporation of chitosan with other nanomaterials was reported to be more suitable for cell growth promotion. A study was done by Li et al ${ }^{61}$ on the incorporation of hydroxyapatite and chitosan for bone tissue engineering applications to enhance their strength. The results evinced that the compressive strength of hydroxyapatite nanocomposite scaffolds shows an increment from 101.67 $\mathrm{MPa}$ to $108.92 \mathrm{MPa}$ upon the addition of $20 \%$ and $40 \%$ of chitosan, respectively. However, the compressive strength begins to decrease when the concentration of chitosan was higher than $50 \%$. This is due to the hydrogen bonding that forms between these materials and chelation between two phases which increased their mechanical properties. These results were in agreement with data gained by Lou et al, ${ }^{66}$ who stated that the compressive strength of poly-(1-lactic acid)/chitosan fiber (PLLA/CTSF) nanocomposite scaffolds increased upon the addition of chitosan fiber. In addition, the in vitro test shows the nanocomposite has potent bioactivity properties. The burn-out test indicates that hydroxyapatite nanoparticles are distributed uniformly into chitosan at a high percentage of chitosan in contrast to low chitosan percentage, the hydroxyapatite nanoparticles not fully attached by chitosan and merely act as a glue to link these grains homogeneously. 


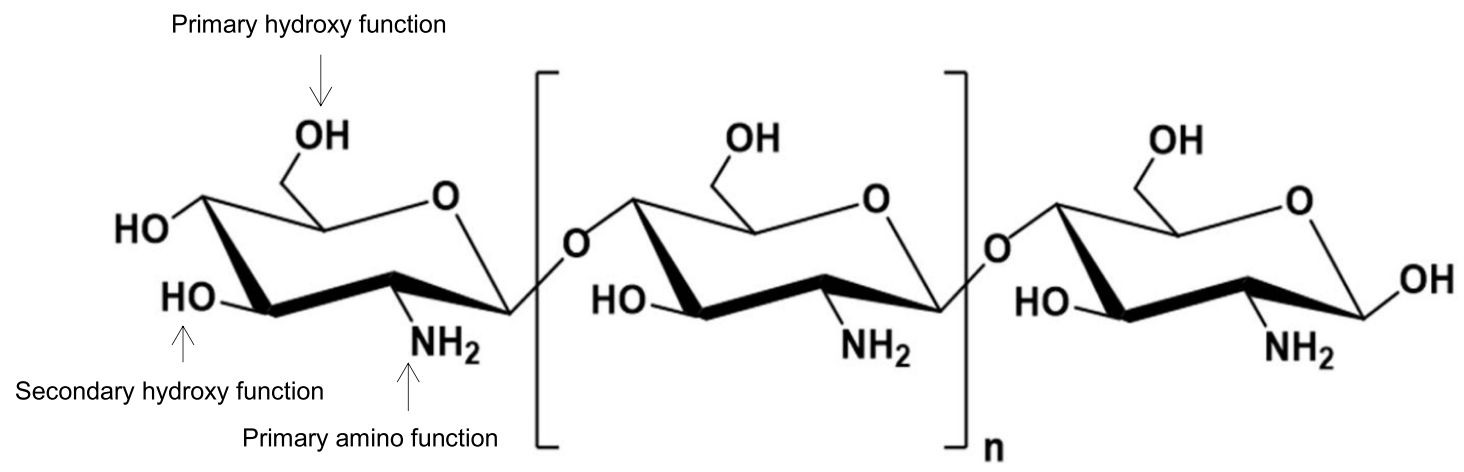

Figure 5 Chemical structure of chitosan.

Notes: Adapted from Sami El-banna F, Mahfouz ME, Leporatti S, El-kemary M, Hanafy NAN. Chitosan as a Natural Copolymer with Unique Properties for the Development of Hydrogels. Appl Sci. 2019;9(II):2193 (doi.org/I0.3390/app9II2193). ${ }^{26}$

The synthesis of chitosan film (CS) was done, incorporating hydroxyapatite/halloysite nanotubes (HA/HNTs) nanocomposite via hydrothermal technique to improve the differentiation and proliferation of MC3T3-E1 preosteoblast cells. ${ }^{120}$ According to SEM analysis results, hydroxyapatite nanoparticles attach to HNTs surface inversely proportionally, and the nanoparticles dispersed uniformly on the surface of the tubes, linked by van der Waals forces ${ }^{115}$ that generated between them. When CS is reinforced to HA/ HNTs nanotubes, the increment in tensile strength and elastic modulus is $48.31 \mathrm{MPa}$ and $1427.4 \mathrm{MPa}$ at dry condition, whereas for pure CS film it is only $28.61 \mathrm{MPa}$ and $856.1 \mathrm{MPa}$, respectively. According to the literature, there are interlinkage forms by CS and nanotubes namely electrostatic interaction and hydrogen bonding. ${ }^{64}$ The authors reveal that the CS reinforcement to HA/HNTs nanocomposites demonstrates good biocompatibility to induce cell differentiation. The acridine orange/ethidium bromide $(\mathrm{AO} / \mathrm{EB})$ staining indicated the cell differentiation and proliferation on $\mathrm{CS} / \mathrm{HA} / \mathrm{HNTs}$ nanocomposite was more preferable to bare $\mathrm{CS}$ and $\mathrm{CS} / \mathrm{HNTs}$ nanocomposites. The experimental data were also in good agreement with alkaline phosphatase (ALP) activity results. The ALP activity of cells, when treated with the lowest ratio of HA/HNTs, 1-1 (denoted as CS/1-1), shows the greatest result among the groups, after 7 days of cell culture. In addition, the mineralization of calcium was significant on hydroxyapatite-containing nanocomposite in contrast to the pure CS film. This is because the hydroxyapatite content influenced the degree of mineralization that leads to calcium deposited on nanocomposite.

The degree of degradation was found to be faster than usual, due to the thermal transfer from hydroxyapatite particles being more efficient, which facilitates the breakdown of the chitosan structure. ${ }^{78}$ However, usually, CS-HA is hybridized with other compounds so that it is suitable for bone regeneration application.

\section{Alginate}

Alginate is a type of anionic polymer that is usually extracted from brown seaweed. ${ }^{62}$ This natural polymer is used extensively as gel due to its features such as low-cost viability and hydrophilicity, and as it is biocompatible and biodegradable in normal physiological conditions. A scaffold made from hydroxyapatite, gelatin and alginate nanocomposite via titration of precursor materials (calcium chloride, sodium biphasic phosphate and gelatin/ alginate solution) was found to be an excellent material to endow the crystallinity, the mechanical strength of hydroxyapatite and particle distribution on the scaffold surface for biomedical applications. ${ }^{104}$ The functional groups of alginate, namely, $\beta$-D-manunronic and $\alpha$ L-gluronic acids, bonded by 1-4 linkages and formed thermally stable calcium alginate upon the addition of calcium ion as shown in Figure 6. ${ }^{1}$

Besides, the hydroxyapatite particles were dispersed homogeneously, and a similar result was also found by Teng et $\mathrm{al},{ }^{104}$ when the alginate was added at $\mathrm{pH}=10 .^{52}$ This is because the negatively charged hydroxyapatite particles were repelling each other in conditions of high $\mathrm{pH}$, and consequently the particles scattered. Furthermore, the interaction between alginate and hydroxyapatite forms stable hydrogels, due to the negative charge of alginate ions attracted to $\mathrm{Ca}^{2+}$ ion in hydroxyapatite, ${ }^{118}$ therefore, it formed a stable complex. ${ }^{52}$ 


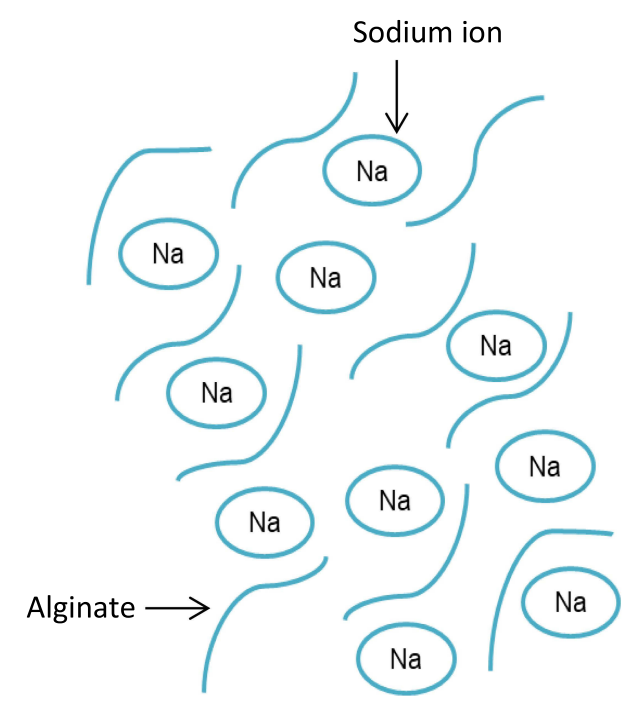

Figure 6 Formation of calcium alginate.

\section{Trigonella Foenum-Graecum Seed Polysaccharide}

Trigonella foenum-graecum seed polysaccharide (TFSP) is an annual leguminous plant usually found in Mediterranean countries, Europe, Northern India, Argentina and Egypt. ${ }^{25}$ The polysaccharide is classified as a bioactive natural polymer and is broadly used in biomedical applications due to its antioxidant, antiviral, antitumor and anti-inflammatory properties. $^{51}$ The hydroxyapatite-chitosan (HA-CS) nanocomposite and TFSP were synthesized via co-precipitation technique by Zia et al. ${ }^{122}$ The nanocomposite was proven suitable for biomedical applications due to its tremendous properties. The porosity of HA-CS nanocomposite reinforced with TFSP was $60.3 \pm 0.17 \%$, ie within the range of cancellous bone, $50-90 \%{ }^{53}$ It proves that the presence of TFSP will increase the porosity and increase the surface area of the scaffold, and therefore it gives a pathway for protein adsorption, nutrient carriage, neo-vascularization, cellular shifting, drug diffusion and also better particle size distribution and surface roughness, which will facilitate cell attachment for tissue growth. This is due to functional groups of hydroxyapatite, CS and TFSP producing equilibrium linkages and forming a chemical bond that will give rise to the porosity of nanocomposite. The porous network structure of the nano-scaffold might be the reason for the better mechanical strength than HA-CS alone. Other than that, the high mechanical strength was also due to the hydrogen bonding produced between nanoparticles and the homogeneous distribution of particles when TFSP was added.

Besides the improvement of mechanical properties, the high water absorption capacity of the nanocomposite was

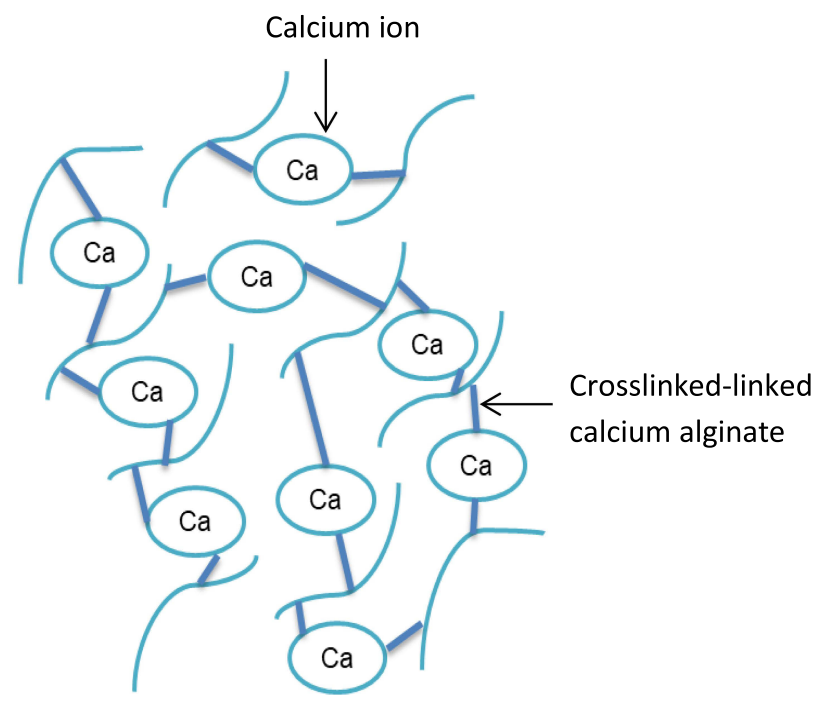

attributed to the porosity structure paralleled with the hydrophilicity nature of TFSP which allows water to penetrate inside. Furthermore, TFSP was found to be compatible with living tissue because it does not have any toxic effect on erythrocytes and the degradation time of the nanocomposite shows more effectiveness instead of its binary nanoparticles in nature. This result is in good agreement with that of Ktari et al, ${ }^{54}$ who observed that no hemolysis occurred even when the TFSP was added to the bovine erythrocytes. Moreover, the minimal inhibitory concentration (MIC) value of the nanocomposite was decreased due to the large surface area of the nanocomposite, which gives better contact and makes it easier to interrupt the cell wall of bacteria. As the MIC value decreases, a low concentration of the nanocomposite is needed to destroy the pathogen. ${ }^{58}$ Therefore, it confirms that the anti-microbial properties of the nanocomposite are better improved upon the existence of TFSP. Nonetheless, the excessive amount of TFSP will increase the toxicity, decreasing cell viability and might have a negative impact on other cells as well. Therefore, the reinforcement of TFSP onto HA-CS nanocomposite will improve the resulting nanocomposite properties for bone tissue engineering.

\section{Hydroxyapatite-Ceramic Nanocomposite Montmorillonite}

An ancient civilization utilized clay for tool making such as cooking utensils, pots and many others. Generally, the properties of clay are high-granularity structure made up of hydrated silicate, called phyllosilicates, and they have 
a diameter as small as $0.004 \mathrm{~nm} .{ }^{106}$ Several groups of clay can be used for various purposes namely talc, serpentine, smectite, etc. New research explores the uses of clay, especially montmorillonite (MMT), in biomedical studies due to their remarkable features. The sandwiched-like structure of montmorillonite consists of two tetrahedral layered and one octahedral at a 2:1 ratio. The presence of MMT can ameliorate the mechanical strength, improve porosity, lessen the fractures and degradation factor. ${ }^{75}$

A scaffold made up of chitosan-hydroxyapatite-zinc oxide incorporated with organically modified montmorillonite $(\mathrm{ZnCMH})$ was synthesized, and the mechanical strength reached the optimum value with the addition of only $5 \%$ of montmorillonite (OMMT), while the strength of the control sample $(\mathrm{ZnCH})$ without OMMT was the lowest. ${ }^{8}$ The authors prepared samples with different percentages (wt\%) of chitosan (CS) and OMMT at a constant ratio of $5 \%$ of hydroxyapatite-zinc oxide (HA- $\mathrm{ZnO})$ and the control contained solely zinc, chitosan and hydroxyapatite $(\mathrm{ZnCH})$ to favor the best properties of nanocomposite scaffold for bone tissue engineering. The tensile strength of all of the samples with OMMT is within the range of human trabecular bone between 10 and $3000 \mathrm{MPa}^{74}$ Cao et al ${ }^{10}$ reported that chitosan-collagen nanocomposite with 5\% addition of montmorillonite (MMT) demonstrates that the microstructures and interconnected pores in the nanocomposite contribute to the increased mechanical strength by maintaining its mechanical stability. Besides, hemolytic assay indicates blood compatibility (not causing harm to erythrocytes) with a value less than $7 \%$ upon the presence of zinc and OMMT. This result proved that the nanocomposite is non-toxic to human blood cells. The percentage of hemolysis that is acceptable is below $5 \%$, and it is precisely stated as highly hemocompatible. ${ }^{41}$ The addition of $5 \%$
OMMT in the nanocomposite is at the optimum as it induces the proliferation of human osteoblastic MG-63 cells, whilst above $10 \%$ of OMMT content in the nanocomposite will hinder the cell growth.

Antibacterial assays of the nanocomposite were studied to indicate the effectiveness of the nanocomposite in combating bacterial growth such as Gram-positive bacteria, Bacillus cereus (B. cereus) and Lysinibacillus fusiformis (L. fusiformis), and Gram-negative bacteria, Escherichia coli (E. coli). ZnCMH I-III (refer to Table 1) nanocomposite exhibits a significant inhibition area against both Gram-positive and Gram-negative strains. This is due to each of the materials in the nanocomposite having good antibacterial properties. Therefore, the inclusion of OMMT is hemocompatible, induces cell proliferation, enhances the antibacterial activity and mechanical strength and makes it suitable for use in bone tissue engineering. Table 1 depicts the effects of OMMT on tensile strength, hemocompatibility, cell growth and antibacterial activity of the nanocomposite.

\section{Zirconia}

Zirconia is known as bijou in ancient civilization. The crystalline dioxide of zirconium has mechanical strength similar to metal and the same color as teeth. ${ }^{70}$ Zirconia can exist in three forms: it is monoclinic (M) at room temperature and stable in low temperature of $1170{ }^{\circ} \mathrm{C}$; above $1170{ }^{\circ} \mathrm{C}$ it converts to the tetragonal (T) phase. When the temperature is higher than $2370^{\circ} \mathrm{C}$, it is in cubic (C) form, and this phenomenon is called polymorphism. Among these three phases, the $\mathrm{T}$ form has the properties of high strength, toughness and is more biocompatible than other phases. After heating to $1500-1700{ }^{\circ} \mathrm{C}$, the surface started to expand and the created stresses lead to the surface breaking into small pieces. ${ }^{30}$ The M-phase is feeble at

Table I Effects of OMMT Towards Tensile Strength, Hemocompatibility, Cell Growth and Antibacterial Activity of HA-Based Nanocomposite

\begin{tabular}{|c|c|c|c|c|c|c|c|c|}
\hline & \multirow{2}{*}{$\begin{array}{l}\text { CTS } \\
\text { (\%wt) }\end{array}$} & \multirow{2}{*}{$\begin{array}{l}\text { OMMT } \\
\text { (\%wt) }\end{array}$} & \multirow{2}{*}{$\begin{array}{c}\text { Tensile } \\
\text { Strength } \\
\text { (MPa) }\end{array}$} & \multirow[t]{2}{*}{ Hemocompatible (\%) } & \multirow{2}{*}{$\begin{array}{l}\text { Proliferation of } \\
\text { MG-63 Cells }\end{array}$} & \multicolumn{3}{|c|}{ Antibacterial Activity (mm) } \\
\hline & & & & & & L. fusiformis & B. cereus & E. coli \\
\hline $\mathrm{ZnCH}$ & 95 & 0 & $16.16 \pm 0.32$ & 5.5 & Lowest & $12.3 \pm 0.62$ & $|1.6 \pm 0.5|$ & 11.259 \\
\hline $\mathrm{ZnCHM} \mathrm{I}$ & 90 & 5 & $30.13 \pm 0.16$ & 4 & Highest & $17.2 \pm 0.72$ & $12.8 \pm 0.62$ & $\begin{array}{r}11.8 \\
\pm 0.57\end{array}$ \\
\hline $\mathrm{ZnCHM} \mathrm{II}$ & 85 & 10 & $29.80 \pm 0.21$ & 5 & Moderate & $18.0 \pm 0.58$ & $13.5 \pm 0.58$ & $\begin{array}{r}12.4 \\
\pm 0.55\end{array}$ \\
\hline $\mathrm{ZnCHM} \mathrm{III}$ & 80 & 15 & $23.07 \pm 0.26$ & 7 & Higher than control & $12.3 \pm 0.62$ & $|4| \pm 0.5 \mid$. & $\begin{array}{r}12.9 \\
\pm 0.68\end{array}$ \\
\hline
\end{tabular}

Notes:Data from Bhowmick A, Lal S, Pramanik N, et al. ${ }^{8}$ 
room temperature, therefore, to prevent the T-phase from being converted to M-phase, a stabilization process is needed. $^{7}$

Zirconia has a macroporous structure that gives it mechanical strength about seven times greater than hydroxyapatite. Therefore several efforts of research have been conducted in the coating of zirconia on hydroxyapatite surface to combine the bioactive properties of hydroxyapatite and mechanical strength of zirconia to produce a better structure and character of calcium phosphate composite for biomedical applications. ${ }^{56,59}$ The large pore size and high porous density help cell proliferation and osteogenesis by enabling transportation of nutrients and gas conversion. ${ }^{121}$

Zhang et $\mathrm{al}^{119}$ employed the digital light processing (DLP) method to synthesize zirconia combined with hydroxyapatite. DLP is a common method used based on its high-speed processing and high precision to improve the competence of new materials. As a result, the mechanical strength of hydroxyapatite was increased, and the toughening effect of zirconia at $1200{ }^{\circ} \mathrm{C}$ and $1250{ }^{\circ} \mathrm{C}$ was also increased. Additionally, the unusual grain growth of pure hydroxyapatite without zirconia addition shows irregular particle size and shape, whilst the presence of zirconia resulted in the uniform microcrystal distribution and grain growth on the hydroxyapatite surface. The grain boundary shifting and grain growth of hydroxyapatite were the consequence of a smaller size of zirconia particles that adhered to the larger surface of zirconia during the sintering process. ${ }^{119}$ This result proves that the introduction of zirconia gives better mechanical strength and toughness to the ceramics. Moreover, the in vitro studies resulted in the elongated growth and assembling of the mouse bone mesenchymal stem cells (mBMSCs) that come from the rough surface of the composite.

\section{Application of}

Hydroxyapatite-Containing

Nanomaterials in Drug Delivery

\section{System}

Osteomyelitis is inflammation of bone commonly caused by bacterial infection during bone implant. The three types of pathogen, namely Staphylococcus (notably Gram-positive S. aureus and S. epidermidis), Enterobacteriaceae and Pseudomonas, are responsible for osteomyelitis. As noted by Jensen et $\mathrm{al}^{40}$ the bacteria were adhered to the bone implants through the formation of biofilm, isolated part on the implant surface. The implant-associated infection arises as a serious problem since it causes perpetuated antimicrobial treatment and non-success of implants, therefore, several research works have been implemented to give us prospects for hampering bacterial adhesion and avoiding implant-related diseases. The traditional prophylaxis which delivers antibiotics (orally or injected) presumably has toxicity to the renal system and liver on account of the high dose of antibiotics intake and incomplete diffusion into the cells. Hence, another prominent area of research, the nanodelivery system, has been developed and administered for targeting drugs directly to diseased cells in the human body as well as minimizing side effects. A nanodelivery system employed nanoscale particles made up of materials designed at the molecular level which are usually tinysized so that they can easily move inside the human body. Nanodelivery systems essentially are intended to: transport the drug locally to the target location of the body in a controlled manner, reduce toxicity and side effects, improve patient relief by lowering the dose ${ }^{108}$ and reducing manufacturing costs. ${ }^{97}$ These systems combining antibiotics with a matrix serve as a vehicle that will transport drugs into desired cells.

There are two categories of matrix, viz. biodegradable and non-biodegradable. A non-biodegradable carrier, for instance, polymethyl methacrylate (PMMA) had been proven to prevent osteomyelitis effectively, but the non-biodegradable feature limits its use as a drug carrier since the beads need to be removed surgically afterward. In consequence, scientists were intrigued to employ biodegradable nanomaterials such as hydroxyapatite due to its privileged characteristics that would create novel opportunities in nanodelivery systems. Apart from biocompatibility and bioactivity properties, the adsorption abilities of hydroxyapatite, as it consists of positively charged surface, $\mathrm{Ca}^{2+}$, attracting anion and negatively charged ions, $\mathrm{PO}_{4}{ }^{3-}$, pairing with cation, make it convenient as a drug nanocarrier.

A study was conducted by Venkatasubbu et al ${ }^{109}$ using alginate-doped hydroxyapatite nanoparticles with ciprofloxacin for drug delivery application. Ciprofloxacin is one of the common drugs widely used to obviate infection during bone implant due to it having a low minimum inhibitory concentration, as low as $0.25-2 \mathrm{mg} / \mathrm{L}$. From the results gained, the drug-matrix ratio influenced the quantity of drug-load, and also $0.8 \mathrm{mg}$ of ciprofloxacin is an optimum amount of drugload for $1 \mathrm{mg}$ hydroxyapatite nanoparticle. At first, the release of ciprofloxacin in a burst in native hydroxyapatite 
nanoparticles is probably due to leakage of hydroxyapatite volume, but the presence of alginate not only extended the drug release time but also release sustainably at a controlled rate. Ciprofloxacin (CFX) was again the choice of antibiotic for Albahy et $\mathrm{al}^{3}$ who investigated nano-hydroxyapatite (nHA) combined with multi-walled carbon nanotubes (MWCNTs) as a drug matrix. The authors disclosed that the hydroxyapatite-doped MWCNTs indicate higher drugload than the native nHA due to influential effects from the MWCNTs. The drug release profile evinced that the prolonged release of CFX would be maintained for months with less of a burst effect and showing the minutest detrimental effects with the highest compliance. K-carrageenan crosslinked hydroxyapatite-chitosan hydrogel nanocomposite (Chito-Car-HA)-loaded CFX was synthesized by Reza et al, ${ }^{88}$ aimed at the sustained release of the antibiotic. At 120 hours, a sustained and prolonged release of CFX was achieved with Chito-Car-HA nanocomposite through diffusion process. This result demonstrates the successful loading of CFX in the nanocomposite through the freeze-drying method. Despite drug release behavior, the authors observed the in vitro antibacterial study against two strains that often cause bone abnormalities and chronic osteomyelitis, viz. E. coli and S. aureus. The nanocomposite-capped CFX hydrogels indicate a significant zone of inhibition of bacterial growth because the CFX drug can mobilize simply in media and punctures the membrane of pathogen cells, hampering the DNA replication and pathogen growth.

Tang et $\mathrm{al}^{103}$ were involved in the synthesis of gentamicin-loaded carbonated hydroxyapatite coatings (CHACs) using the lyophilization method. The CHACs were deposited on titanium plates and loaded in gentamicin solution at different doses. CHACs-loaded gentamicin indicates outstanding drug loading in comparison with titanium plates due to: (1) the surface area of CHACs increases the active sites of $\mathrm{Ca}^{2+}$ and $\mathrm{PO}_{4}{ }^{3-}$ groups that would increase the affinity of carrier towards gentamicin antibiotic; (2) the mesopores and macropores present in the CHACs' structure control the drug diffusion at a specific rate as well as providing space for drug loading events; and lastly, (3) a low crystallinity of CHACs consists of interstitial space that would provide more active sites for drug molecule adsorption.

Contrastingly, titanium plates show low drug efficiency because of a lack of pores in their structure and an inappropriate surface area for drug loading. Consequently, there was no gentamicin release from titanium plate neither in low doses nor high doses because of low drug loading property and physical adsorption of gentamicin leading to drug leaking when soaking in PBS solution. As was foreseeable, the drug release profiles of gentamicin in CHACs plates present a stable and prolonged release up to 24 hours for both doses. The hydrogen bonding that held CHACs and gentamicin restrains the instant release of gentamicin from CHACs. Similarly, gentamicin-doped hydroxyapatite NPs complexed on coated titanium were prepared by the sol-gel coatings method and successfully demonstrated in drug delivery applications. ${ }^{79}$ The authors evinced that the gentamicin was released within the time frame for prophylaxis during the periand post-operative period, which is up to $99 \%$ at a controlled rate after 48 hours. The addition of BMP- 2 on the coating did not release tremendously, and it is not necessary for stimulating BMSC differentiation as well as promoting bone healing. Table 2 portrays a few examples of hydroxyapatite-based nanocomposites in drug delivery systems.

\section{Recent Patents on the Integration of Hydroxyapatite-Nanomaterials for Bone Tissue Engineering and Drug Delivery System}

The hydroxyapatite-based nanocomposite scaffold has been explored widely in biomedical applications.

Table 2 HA-Based Nanocomposites for Drug Delivery System

\begin{tabular}{|c|c|c|c|c|}
\hline HA Nanocomposites & Drug Used & Drug Release Properties & Antibacterial Activity & Reference \\
\hline HA-alginate & Ciprofloxacin & - & - & [6] \\
\hline HA-MWCNTs & Ciprofloxacin & Sustained-release for a month & - & [3] \\
\hline HA-K-carrageenan-chitosan & Ciprofloxacin & Sustained-release at 120 hours & $\begin{array}{c}\text { A significant zone of inhibition against } \\
\text { E. coli and S. aureus }\end{array}$ & [88] \\
\hline $\begin{array}{l}\text { Carbonated HA coatings on } \\
\text { titanium plates }\end{array}$ & Gentamicin & Sustained-release up to 24 hours & $\begin{array}{c}\text { A high content of gentamicin against } \\
\text { S. epidermis }\end{array}$ & {$[103]$} \\
\hline HA-coated titanium & Gentamicin & Sustained-release after 48 hours & $\begin{array}{c}\text { Partially eliminates S. aureus and } \\
\text { S. epidermis }\end{array}$ & [79] \\
\hline
\end{tabular}


Table 3 Recent Patents on Hydroxyapatite-Based Nanocomposites for Bone Tissue Engineering

\begin{tabular}{|c|c|c|c|}
\hline Patents/Year & Method of Invention & Claims & Reference \\
\hline CN II $0665055 / 2020$ & $\begin{array}{l}\text { The scaffold is produced by mixing calcium nitrate } \\
\text { and ammonium phosphate to synthesize } \\
\text { hydroxyapatite, the sericin solution taken from } \\
\text { silkworm cocoons after being immersed in } \\
\text { a lithium bromide aqueous solution. }\end{array}$ & $\begin{array}{l}\text { A complex porous scaffold derived from sericin } \\
\text { and nano-hydroxyapatite used as a carrier to } \\
\text { monitor the growth factors of bone morphogen } 2 \\
\text { by detecting the loading and release of the } \\
\text { osteogenesis process. }\end{array}$ & [20] \\
\hline CN II $0898257 / 2020$ & $\begin{array}{l}\text { Polymerization of polylactide-propylene glycol } \\
\text { methacrylate and hydroxyapatite. }\end{array}$ & $\begin{array}{l}\text { The photocurable composite produced for bone } \\
\text { tissue engineering to improve the mechanical } \\
\text { property, biocompatibility, biodegradability and } \\
\text { porosity without using a toxic solvent. }\end{array}$ & {$[114]$} \\
\hline CN II $0639060 / 2020$ & $\begin{array}{l}\text { 3D bio-printed silk fibroin-based bone tissue } \\
\text { engineering scaffold was prepared by mixing the } \\
\text { silk fibroin fibers, lithium bromide, gelatin, } \\
\text { hydroxyapatite and hyaluronic acid. }\end{array}$ & $\begin{array}{l}\text { The 3D bioprinting silk fibroin produced from } \\
\text { a short material preparation process with high } \\
\text { solubility property to engage in body metabolism } \\
\text { to induce the growth of osteoblast, non-toxic and } \\
\text { cheap. }\end{array}$ & [63] \\
\hline CN $109260525 / 2019$ & $\begin{array}{l}\text { Calcium phosphate-based bioactive ceramic } \\
\text { printing ink was prepared by mixing } \\
\text { hydroxyapatite, tricalcium phosphate (TCP), } \\
\text { binder (PVA) and ethanol. } \\
\text { The 3D printing scaffold is produced using three- } \\
\text { dimensional inkjet printing, selective laser etching } \\
\text { (SLS), stereo light-curing molding and digital light } \\
\text { processing (DLP). }\end{array}$ & $\begin{array}{l}\text { The 3D-printing technology is used for controlling } \\
\text { the shape and microporous structure of scaffold } \\
\text { to repair hard tissue. }\end{array}$ & [14] \\
\hline CN 109758609/2019 & $\begin{array}{l}\text { The 3D scaffold produced by mixing calcium } \\
\text { chloride, zinc chloride, deionized water, creatine } \\
\text { phosphate, chitosan and silk fibroin. }\end{array}$ & $\begin{array}{l}\text { The composite that is composed of more than } \\
\text { one material is preferred to improve the scaffold } \\
\text { performance with a fine method of synthesis, } \\
\text { simple and low cost. }\end{array}$ & [16] \\
\hline CNI09589450/2019 & $\begin{array}{l}\text { The method to synthesis-guided bone tissue } \\
\text { regeneration is simple by mixing MXene and } \\
\text { synthetic hydroxyapatite nanowires in a specific } \\
\text { condition. }\end{array}$ & $\begin{array}{l}\text { The addition of MXene as guided bone tissue } \\
\text { regeneration material to separate different } \\
\text { epithelial tissue in the growing process, as well as } \\
\text { act as a supporter for bone scaffold and, } \\
\text { potentially, prevent any infection. }\end{array}$ & {$[117]$} \\
\hline US $2018007 \mid 433 / 2018$ & $\begin{array}{l}\text { The porous scaffold comprised: porous tannin } \\
\text { powder particles, dried polyethylene glycol } \\
\text { particles, hydroxyapatite, organic acid, } \\
\text { formaldehyde solution and biodegradable polymer } \\
\text { (polyurethane, polylactic acid, etc). }\end{array}$ & $\begin{array}{l}\text { The bone graft is biocompatible with optimum } \\
\text { porosity and pore diameter, high compressive } \\
\text { strength and osteocompotent of stem cells } \\
\text { stimulate bone growth. }\end{array}$ & [99] \\
\hline CN $108339152 / 2018$ & $\begin{array}{l}\text { A mixture containing aliphatic polyester- } \\
\text { polyethylene glycol block copolymer, Span-80, } \\
\text { Tween-60, stabilizer and silver nitrate. }\end{array}$ & $\begin{array}{l}\text { The loaded silver nanoparticles can provide } \\
\text { bacteriostatic activity, and the loaded } \\
\text { hydroxyapatite provides osteogenic activity. }\end{array}$ & [86] \\
\hline CN 108297396/2018 & $\begin{array}{l}\text { Mix gelatin, sodium alginate, water, nanoscale } \\
\text { hydroxyapatite with the first freeze-drying } \\
\text { treatment, curing treatment, cleaning and second } \\
\text { freeze drying to produce a bone tissue } \\
\text { engineering scaffold. }\end{array}$ & $\begin{array}{l}\text { The 3D bone tissue engineering scaffold is } \\
\text { produced through extrusion deposition type } 3 D \\
\text { printing, and this method will strengthen } \\
\text { hydroxyapatite and increase the biological affinity } \\
\text { of the scaffold. }\end{array}$ & [47] \\
\hline
\end{tabular}

(Continued) 
Table 3 (Continued).

\begin{tabular}{|c|c|c|c|}
\hline Patents/Year & Method of Invention & Claims & Reference \\
\hline CN $107982578 / 2018$ & $\begin{array}{l}\text { The scaffold produced by reacting these materials: } \\
\beta \text {-cyclodextrin (soft segment component for } \\
\text { polyurethane synthesis), hexamethylene } \\
\text { diisocyanate (hard segment component), nano- } \\
\text { hydroxyapatite and stannous octoate (catalyst). }\end{array}$ & $\begin{array}{l}\text { The nanocomposite scaffold has a porous } \\
\text { structure with good biocompatibility and } \\
\text { mechanical properties and a simple method with } \\
\text { low cost. }\end{array}$ & [23] \\
\hline CN $106421894 / 2017$ & $\begin{array}{l}\text { Hydroxyapatite powder undergoes surface } \\
\text { modification by stearic acid, mixing the } \\
\text { hydroxyapatite powder and a poly-L-lactic acid } \\
\text { solution and electrostatic spinning on a mixed } \\
\text { solution. }\end{array}$ & $\begin{array}{l}\text { The scaffold has a connected porous structure } \\
\text { that gives a pathway for nutrient transmission, the } \\
\text { hydroxyapatite material is not degraded easily, } \\
\text { while the product of the degradation process is } \\
\text { useful for human metabolism. }\end{array}$ & [27] \\
\hline CN $106512099 / 2017$ & $\begin{array}{l}\text { The method used in producing bone tissue } \\
\text { engineering scaffold is by mixing chitosan, acetic } \\
\text { acid, sodium hydroxide, deionized water and } \\
\text { calcium chloride and dipotassium phosphate, to } \\
\text { generate hydroxyapatite. }\end{array}$ & $\begin{array}{l}\text { The scaffold has high compressive strength (I.5- } \\
4.5 \mathrm{MPa} \text { ), larger pore size, uniform distribution of } \\
\text { nano-acicular hydroxyapatite and better biological } \\
\text { activity. }\end{array}$ & [43] \\
\hline CN 107/58477/2017 & $\begin{array}{l}\text { The ratio amount of hydroxyapatite/collagen } \\
\text { powder added is } 0.2-0.1 \% \text { of lactoferrin then, } \\
\text { filter and centrifuge at the suitable condition. The } \\
\text { end product will be a freeze-dried process to } \\
\text { remove impurities. }\end{array}$ & $\begin{array}{l}\text { The composites have good biocompatibility, and } \\
\text { the addition of lactoferrin will improve the } \\
\text { osteogenic activity of the composite. The } \\
\text { hydroxyapatite/collagen composite can release } \\
\text { lactoferrin at an optimum rate. }\end{array}$ & [7I] \\
\hline CN $105963789 / 2016$ & $\begin{array}{l}\text { The scaffold materials comprise gelatin, deionized } \\
\text { water, hydroxyapatite, stearic acid (pore former), } \\
\text { ethanol and glutaraldehyde (aid in the cross- } \\
\text { linking process). }\end{array}$ & $\begin{array}{l}\text { The method used to produce bone tissue scaffold } \\
\text { is low cost, uses non-toxic materials, modifies the } \\
\text { pore size of the scaffold to an optimum size and } \\
\text { strengthens the hydroxyapatite up to } 30 \mathrm{MPa} \text {. }\end{array}$ & [113] \\
\hline US $20150343117 / 2015$ & $\begin{array}{l}\text { The method used to produce collagen/HA } \\
\text { composites directed press a collagen scaffold into } \\
\text { a perfusion chamber of a closed-loop perfusion } \\
\text { flow system and constantly delivering } \\
\text { a mineralization perfusion fluid via collagen } \\
\text { scaffold at an optimum rate and produce collagen/ } \\
\text { HA composites. }\end{array}$ & $\begin{array}{l}\text { The collagen/HA composites that are prepared } \\
\text { using dynamic intrafibrillar mineralization are able } \\
\text { to give a stable environment with low } \\
\text { cytotoxicity, biodegradable and convenient for } \\
\text { human mesenchymal stem cell (hMSC) growth. }\end{array}$ & [42] \\
\hline
\end{tabular}

Scientists tend to merge hydroxyapatite with other materials such as metals, polymers, ceramics, etc. Table 3 presents recent patents on hydroxyapatite-based nanocomposites combined with other substances for bone tissue engineering and drug delivery systems.

\section{Conclusion}

Among the nanomaterials, hydroxyapatite, which has a low cost, chemical similarity to the human bone, good bioactivity, biocompatibility and osteoconductivity, shows potential use as a material bone implant and drug carrier. Hydroxyapatite nanoparticles can be produced either naturally or synthetically by several methods, namely dry, wet and thermal methods. No matter what method was adopted, the control of particle size and surface morphology is still arduous until today. Furthermore, every method has pros and cons, in terms of morphology, stoichiometry, the crystallinity of synthesized hydroxyapatite, which depends upon its final application prerequisites in the biomedical area. Hence, these criteria should be fulfilled while employing a processing technique for the synthesis of hydroxyapatite nanocomposites.

From the bone tissue engineering viewpoint, the application of hydroxyapatite as a material bone implant is gaining prominence in the biomedical field. However, many research works reported that incorporation of hydroxyapatite with other nanomaterials is more suitable for bone replacement in comparison with native hydroxyapatite due to its limitation, 
especially low mechanical strength and antibacterial activity. An alternative approach focuses on enhancing the mechanical strength of hydroxyapatite so that it can withstand considerable stress to support cell growth as well as inhibit the growth of bacteria in bone tissue engineering applications. The combination of hydroxyapatite and other nanomaterials, viz. metals, polymers and ceramics, was proven to improve mechanical strength and antibacterial properties of hydroxyapatite without altering its morphology. Besides, a new formulation of hydroxyapatite is also intended to deliver drugs locally to a specific site of the human body. Necessarily, besides possessing biocompatibility, bioactivity and biodegradability features, bone-implant nanomaterials must have tolerable drug delivery properties and antibacterial properties without leaving any systemic toxicity effects.

\section{Way Forward}

Hydroxyapatite-based nanocomposite for biomedical applications has gained great interest due to its ability to communicate well with inside body components. To date, researchers are still working on ideal materials that can interact with hydroxyapatite, mimicking bone scaffolds while delivering drugs to targeted cells. It is also important to fully study the biological behavior of these substituted materials, and further studies, especially in vitro and in vivo, are necessary so that the process mechanisms such as biocompatibility, biodegradation, integration of bone cell as well as drug release behavior with the nanocomposite scaffold can be well understood. In addition, the ideal characteristics of a scaffold structure need to be evaluated to develop a hydroxyapatite-based scaffold with an optimum drug release system. This paves a new path for clinical studies.

\section{Funding}

This project was supported by the Ministry of Higher Education of Malaysia under the Fundamental Research Grant Scheme, FRGS/1/2018/STG07/UPM/01/2, Vot no. 5540162 .

\section{Disclosure}

The authors declare no conflicts of interest in this work.

\section{References}

1. Abasalizadeh F, Moghaddam SV, Alizadeh E, et al. Alginate-based hydrogels as drug delivery vehicles in cancer treatment and their applications in wound dressing and 3D bioprinting. $J$ Biol Eng. 2020;14(1):1-22.
2. Ai F, Chen L, Yan J, et al. Hydroxyapatite scaffolds containing copper for bone tissue engineering. J Solgel Sci Technol. 2020;95 (1):1-40. doi:10.1007/s10971-020-05285-0

3. Albahy GS, Abbas YM, Hezma AM, et al. Preparation of porous n-HAp scaffold enforced with MWCNTs as vehicle for local drug delivery of ciprofloxacin. J Text Color Polymer Sci. 2020;17(1):77-85.

4. Alorku K, Manoj M, Yuan A. A plant-mediated synthesis of nanostructured hydroxyapatite for biomedical applications: a review. RSC Adv. 2020;10:40923-40939. doi:10.1039/D0RA08529D

5. Bari A, Bloise N, Fiorilli S, et al. Copper-containing mesoporous bioactive glass nanoparticles as multifunctional agent for bone regeneration. Acta Biomaterialia. 2017;55:493-504. doi:10.1016/ j.actbio.2017.04.012

6. Benedini L, Laiuppa J, Santillán G, et al. Antibacterial alginate/ nano-hydroxyapatite composites for bone tissue engineering: assessment of their bioactivity, biocompatibility and antibacterial activity. Mater Sci Eng C. 2020;115:111101. doi:10.1016/j.msec.2020.111101

7. Bermúdez-Reyes B, Del Refugio Lara-Banda M, Reyes-Zarate E, et al. Effect on growth and osteoblast mineralization of hydroxyapatite-zirconia $\left(\mathrm{HA}-\mathrm{ZrO}_{2}\right)$ obtained by a new low temperature system. Biomed Mater. 2018;13(3):035001. doi:10.1088/ 1748-605X/aaa3a4

8. Bhowmick A, Lal S, Pramanik N, et al. Organically modified clay supported chitosan/hydroxyapatite-zinc oxide nanocomposites with enhanced mechanical and biological properties for the application in bone tissue engineering. Int $J$ Biol Macromol. 2018;106:11-19. doi:10.1016/j.ijbiomac.2017.07.168

9. Canillas M, Rivero R, Garcia-Carrodeguas R, et al. Processing of hydroxyapatite obtained by combustion synthesis. Boletin De La Sociedad Espanola DeCerámica y Vidrio. 2017;56(5):1-6.

10. Cao X, Wang J, Liu M, et al. Chitosan-collagen/organomontmorillonite scaffold for bone tissue engineering. Front Mater Sci. 2015;9(4):405-412. doi:10.1007/s11706-015-0317-5

11. Cardozo VF, Oliveira AG, Nishio EK, et al. Antibacterial activity of extracellular compounds produced by a Pseudomonas strain against methicillin-resistant Staphylococcus aureus (MRSA) strains. Ann Clin Microbiol Antimicrob. 2013;12(1):1-8. doi:10.1186/1476-0711-12-12

12. Cestari F, Agostinacchio F, Galotta A, et al. Nano-hydroxyapatite derived from biogenic and bioinspired calcium carbonates: synthesis and in vitro bioactivity. Nanomaterials. 2021;11(2):1-14. doi:10.3390/nano11020264

13. Ceylan M, Akdas S, Yazihan N. Is zinc an important trace element on bone-related diseases and complications? A meta-analysis and systematic review from serum level, dietary intake, and supplementation aspects. Biol Trace Elem Res. 2021;199(2):535-549. doi:10.1007/s12011-020-02193-w

14. Changchun Z, Yujiang F, Boqing $Z$, et al., inventor; UNIV Sichuan., assignee. Degradable controllable bone tissue engineering scaffold based on $3 \mathrm{D}$ printing and preparation method thereof. China patent CN 109260525. 2019 Jan 25.

15. Chasapis C, Ntoupa P, Spiliopoulou C, et al. Recent aspects of the effects of zinc on human health. Arch Toxicol. 2020;94 (5):1443-1460. doi:10.1007/s00204-020-02702-9

16. Chen L, Xiaoning H, Jinjie S, Yaping P, Lin L, Shiwen Y, inventor; Hospital of Stomatology China Medical Univ., assignee. Preparation method of composite bone tissue engineering stent material. China patent CN 109758609. 2019 May 17.

17. Chen Y, Han P, Vandi LJ, et al. A biocompatible thermoset polymer binder for direct ink writing of porous titanium scaffolds for bone tissue engineering. Mater Sci Eng C. 2019;25:160-165. doi:10.1016/j.msec.2018.10.033

18. Chlanda A, Heljak M, Górecka Z, et al. Nanohydroxyapatite adhesion to low temperature plasma modified surface of 3D-printed bone tissue engineering scaffolds - qualitative and quantitative study. Surf Coat Tech. 2019;375:637-644. 
19. Cho SJ, Uddin MJ, Alaboina P, et al. Chapter three - review of nanotechnology for cathode materials in batteries. In: RodriguezMartinez LM, Omar N, editors. Emerging Nanotechnology in Rechargeable Energy Storage Systems. Amsterdam: Elsevier; 2017:83-129.

20. Chunlei H, Libing Z, Yeshun Z, inventor; Hospital Of Gannan Medical Univ; Shenzhen Beian Gene Bio Tech Co LTD., assignee. Sericin/nano-hydroxyapatite tissue engineering bone graft as well as preparation method and application thereof. China patent CN 110665055. 2020 Jan 10.

21. Crémet L, Broquet A, Brulin B, et al. Pathogenic potential of Escherichia coli clinical strains from orthopedic implant infections towards human osteoblastic cells. Pathog Dis. 2015;73(8): ftv065. doi:10.1093/femspd/ftv065

22. Dehghanghadikolaei A, Fotovvati B. Coating techniques for functional enhancement of metal implants for bone replacement: a review. Materials. 2019;12(11):1-23. doi:10.3390/ma12111795

23. Di H, Jingjing $\mathrm{D}$, Yan $\mathrm{W}$, et al., inventor; Univ Taiyuan Technology., assignee. Preparation method for nano hydroxyapatite/cyclodextrin-based polyurethane composite porous bone tissue engineering bracket material. China patent $\mathrm{CN}$ 107982578. 2018 May 04

24. Dinda S, Bhagavatam A, Alrehaili $\mathrm{H}$, et al. Mechanochemical synthesis of nanocrystalline hydroxyapatite from $\mathrm{Ca}\left(\mathrm{H}_{2} \mathrm{PO}_{4}\right)_{2} \cdot \mathrm{H}_{2} \mathrm{O}, \mathrm{CaO}$, $\mathrm{Ca}(\mathrm{OH})_{2}$, and $\mathrm{P}_{2} \mathrm{O}_{5}$ mixtures. Nanomaterials. 2020;10: 2232. doi:10.3390/nano10112232

25. Dini I. Spices and herbs as therapeutic foods. In: Holban AM, Grumezescu AM, editors. Food Quality: Balancing Health and Disease. United States: Academic Press; 2018:433-469.

26. Sami El-banna F, Mahfouz ME, Leporatti S, El-Kemary M, A. N. Hanafy N. Chitosan as a natural copolymer with unique properties for the development of hydrogels. Appl Sci. 2019;9 (11):2193. doi:10.3390/app9112193

27. Fengcang M, Ping L, Xinkuan L, et al., inventor; Univ Shanghai Science \& Tech., assignee. Bone tissue engineering timbering material and preparation method thereof. China patent CN 106421894. 2017 Feb 10.

28. Fernandes MH, Alves MM, Cebotarenco M, et al. Citrate zinc hydroxyapatite nanorods with enhanced cytocompatibility and osteogenesis for bone regeneration. Mater Sci Eng C. 2020;115:111147. doi:10.1016/j.msec.2020.111147

29. Filho PM, Barreto MA, Medrado AR, et al. Biological principles of nanostructured hydroxyapatite associated with metals: a literature review. Insight Biomed. 2019;4(3):1-10.

30. Garvie RC, Nicholson PS. Structure and thermomechanical properties of partially stabilized zirconia in the $\mathrm{CaO}-\mathrm{ZrO}_{2}$ system. J Am Ceram Soc. 1972;55(3):152-157. doi:10.1111/j.1151-2916. 1972.tb11241.x

31. George A, Antoni D, Raj A, et al. Temperature effect on $\mathrm{CuO}$ nanoparticles: antimicrobial activity towards bacterial strains. Surf Interfaces. 2020;21:100761. doi:10.1016/j.surfin.2020.100761

32. Gibson IR. 1.3.4A Natural and synthetic hydroxyapatite. In: Wagner WR, Sakiyama-Elbert SE, Zhang G, editors. Biomaterials Science. 4th ed. United Kingdom: Academic Press; 2021:307-317.

33. Gomes DS, Santos AMC, Neves GA, et al. A brief review on hydroxyapatite production and use in biomedicine. Ceramica. 2019;65:282-302. doi:10.1590/0366-69132019653742706

34. Grass G, Rensing C, Solioz M. Metallic copper as an antimicrobial surface. Appl Environ Microbiol. 2011;77(5):1541-1547. doi:10.1128/AEM.02766-10

35. Guo C, Li L, Li S, et al. Preparation, characterization, bioactivity and degradation behavior: in vitro of copper-doped calcium polyphosphate as a candidate material for bone tissue engineering. RSC Adv. 2017;7(67):42614-42626. doi:10.1039/ C7RA06159E
36. Habibah TU, Amlani DV, Brizuela M. Hydroxyapatite dental material. In: Stat Pearls [Internet]. StatPerals Publishing; 2020. Available from: https://pubmed.ncbi.nlm.nih.gov/30020686/. Accessed August 31, 2021.

37. Huang $\mathrm{M}, \mathrm{Ye} \mathrm{K}, \mathrm{Hu} \mathrm{T}$, et al. Silver nanoparticles attenuate the antimicrobial activity of the innate immune system by inhibiting neutrophil-mediated phagocytosis and reactive oxygen species production. Int $J$ Nanomedicine. 2021;16:1345-1360. doi:10.21 47/IJN.S292482

38. Hung YH, Bush AI, Cherny RA. Copper in the brain and Alzheimer's disease. J Biol Inorg Chem. 2010;15(1):61-76.

39. Javadinejad HR, Ebrahimi-Kahrizsangi R. Thermal and kinetic study of hydroxyapatite formation by solid-state reaction. Int J Chem Kinet. 2020;53:583-595. doi:10.1002/kin.21467

40. Jensen LK, Koch J, Aalbæk B, et al. Early implant-associated osteomyelitis results in a peri-implanted bacterial reservoir. Apmis. 2017;125(1):38-45. doi:10.1111/apm.12597

41. Jesus C, Perera C, Guadalupe M, et al. Characterization and hemocompatibility assessment of porous composite scaffolds with a biomimetic human clavicle macrostructure. Health Technol (Berl). 2020;10:423-428. doi:10.1007/s12553-019-003 74-9

42. Jian L, Ben B, Xingguo C, Jeffrey NB, Xiao-Dong C, inventor; Southwest Res Inst., assignee. Fabrication of bone regeneration scaffolds and bone filler material using a perfusion flow system. United State patent US 2015343117. 2015 Dec 03.

43. Jingbo Y, Zhen H, inventor; Univ Shanghai., assignee. Chitosanbased bionic bone tissue engineering scaffold and production method thereof. China patent CN 106512099. 2017 Mar 22.

44. Kakakhel M, Wu F, Sajjad W, et al. Long-term exposure to high-concentration silver nanoparticles induced toxicity, fatality, bioaccumulation and histological alteration in fish (Cyprinus carpio). Environ Sci Eur. 2021;33(14):1-11. doi:10.1186/s123 02-021-00453-7

45. Kalaiselvi V, Mathammal R, Vijayakumar S, et al. Microwave assisted green synthesis of hydroxyapatite nanorods using Moringa oleifera flower extract and its antimicrobial applications. Int J Vet Sci Med. 2018;6(2):286-295. doi:10.1016/ j.ijvsm.2018.08.003

46. Kalbarczyk M, Szczes A, Sternik D. The preparation of calcium phosphate adsorbent from natural calcium resource and its application for copper ion removal. Environ Sci Pollut Res. 2021;28:1725-1733. doi:10.1007/s11356-020-10585-7

47. Kang L, Xianglin Z, inventor; Univ Huazhong Science \& Tech Ezhou Ind Tech Res Inst; Univ Huazhong Science Tech., assignee. Method for manufacturing three-dimensional bone tissue engineering bracket through extruding deposited 3D printing. China patent CN 108297396. 2018 Jul 20.

48. Kavasi R, Coelho C, Platania V, et al. In vitro biocompatibility assessment of nano-hydroxyapatite. Nanomaterials. 2021;11 (5):1-155. doi:10.3390/nano11051152

49. Kaviya M, Ramakrishnan P, Mohamed SB, et al. Synthesis and characterization of nano-hydroxyapatite/graphene oxide composite materials for medical implant coating applications. Mater Today: Proc. 2020;36(2):1-4.

50. Khan MUA, Abdul RSI, Mehboob H, et al. Synthesis and characterization of silver-coated polymeric scaffolds for bone tissue engineering: antibacterial and in vitro evaluation of cytotoxicity and biocompatibility. ACS Omega. 2021;6(6):4335-4346. doi:10. 1021/acsomega.0c05596

51. Kia AG, Ganjloo A. A short extraction time of polysaccharides from fenugreek (trigonella foencem graecum) seed using continuous ultrasound acoustic cavitation: process optimization, characterization and biological activities. Food Bioproc Tech. 2018;11:2204-2216. doi:10.1007/s11947-0182178-2 
52. Kim HL, Jung GY, Yoon JH, et al. Preparation and characterization of nano-sized hydroxyapatite/alginate/chitosan composite scaffolds for bone tissue engineering. Mater Sci Eng C. 2015;54:20-25. doi:10.1016/j.msec.2015.04.033

53. Kim TR, Kim MS, Goh TS, et al. Evaluation of structural and mechanical properties of porous artificial bone scaffolds fabricated via advanced TBA-based freeze-gel casting technique. Appl Sci. 2019;9(9):1-17.

54. Ktari N, Trabelsi I, Bardaa S, et al. Antioxidant and hemolytic activities, and effects in rat cutaneous wound healing of a novel polysaccharide from fenugreek (Trigonella foenum-graecum) seeds. Int J Biol Macromol. 2017;95:625-634. doi:10.1016/j. ijbiomac.2016.11.091

55. Kumar R, Bagri P, Bajpai AK, et al. Nano-silver hydroxyapatite based antibacterial 3D scaffolds of gelatin/alginate/poly (vinyl alcohol) for bone tissue engineering applications. Colloids Surf B Biointerfaces. 2019;177(2):211-218. doi:10.1016/j.colsurfb.20 19.01 .064

56. Lai W, Chen C, Ren X, et al. Hydrothermal fabrication of porous hollow hydroxyapatite microspheres for a drug delivery system. Mater Sci Eng C. 2016;62:166-172. doi:10.1016/j.msec.2016. 01.055

57. Lamkhao S, Phaya M, Jansakun C, et al. Synthesis of hydroxyapatite with antibacterial properties using a microwave-assisted combustion method. Sci Rep. 2019;9:4019. doi:10.1038/s41598019-40488-8

58. Leigue L, Montiani-Ferreira BA, Moore BA. Antimicrobial susceptibility and minimal inhibitory concentration of Pseudomonas aeruginosa isolated from septic ocular surface disease in different animal species. Open Vet J. 2016;6(3):215-222. doi:10.4314/ovj. v6i3.9

59. Lew KS, Othman R, Ishikawa K, et al. Macroporous bioceramics: a remarkable material for bone regeneration. J Biomater Appl. 2012;27(3):345-358. doi:59

60. Li G, Niu W. Chapter 1: challenges toward musculoskeletal injuries and diseases. In: Razavi M, editor. Nanoengineering in Musculoskeletal Regeneration. San Diego, United States: Academic Press; 2020:1-41.

61. Li Z, Yubao L, Aiping Y, et al. Preparation and in vitro investigation of chitosan/nano-hydroxyapatite composite used as bone substitute materials. J Mater Sci Mater Med. 2005;16:213-219.

62. Li Z, Ramay HR, Hauch KD, et al. Chitosan - alginate hybrid scaffolds for bone tissue engineering. Biomaterials. 2005;26: 3919-3928. doi:10.1016/j.biomaterials.2004.09.062

63. Liang W, Runjun S, Chengkun L, Zhaohuan Z, Xue M, Jie D, inventor; Univ Xian Polytechnic., assignee. 3D bioprinting silk fibroin based tissue engineering scaffold and preparation method and application thereof. China patent CN 110639060. 2020 Mar 03.

64. Liu M, Wu C, Zhou C. Chitosan-halloysite nanotubes nanocomposite scaffolds for tissue engineering. $J$ Mater Chem $B$. 2013;1:2078-2089. doi:10.1039/c3tb20084a

65. Lotsari A, Rajasekharan A, Halvarsson M, et al. Transformation of amorphous calcium phosphate to bone-like apatite. Nat Commun. 2018;9(1):1-11. doi:10.1038/s41467-018-06570-x

66. Lou T, Wang X, Yan X, et al. Fabrication and biocompatibility of poly(1-lactic acid) and chitosan composite scaffolds with hierarchical microstructures. Mater Sci Eng C. 2016;64:341-345. doi:10.1016/j.msec.2016.03.107

67. Lutzweiler G, Halili AN, Vrana NE. The overview of porous, bioactive scaffold as instructive biomaterials for tissue regeneration and their clinical translation. Pharmaceutics. 2020;12 (7):1-29. doi:10.3390/pharmaceutics12070602

68. Lyons MK, Kalani M, Neal MT, et al. Surgical management of thoracic osteomyelitis due to Escherichia Coli sepsis. Case Rep Orthop. 2020;2020: Article ID 8847504. doi:10.1155/2020/ 8847504
69. Maertens RL, Matroule J, Houdt RV. Characteristics of the copper-induced viable-but-non culturable state. World J Microbiol Biotechnol. 2021;37(37):1-9. doi:10.1007/s11274021-03006-5

70. Manicone PF, Rossi P, Raffaelli L. An overview of zirconia ceramics: basic properties and clinical applications. J Dent. 2007;35(11):819-826. doi:10.1016/j.jdent.2007.07.008

71. Ming D, Pujie S, Cuiping Y, Meng L, Fengjiao F, Di W, inventor; Univ Dalian Polytechnic., assignee. Preparation method of novel biomaterial based on lactoferrin activity. China patent $\mathrm{CN}$ 107158477. 2017 Sept 15.

72. Mirjalili F, Navabazam A, Samanizadeh N. Preparation of hydroxyapatite nanoparticles from natural teeth. Russ $J$ Nondestruct Test. 2021;57:152-162. doi:10.1134/S1061830921020091

73. Morgan EF, Gerstenfeld LC. Chapter 2- The bone organ system: form and function. In: Dempster DW, Cauley JA, Bouxsein ML, editors. Marcus and Feldman's Osteoporosis. 5th ed. United States: Academic Press; 2021:15-32.

74. Morgan EF, Unnikrisnan GU, Hussein AI. Bone mechanical properties in healthy and diseased states. Annu Rev Biomed Eng. 2018;20:119-143. doi:10.1146/annurev-bioeng-062117121139

75. Mousa M, Evans ND, Oreffo ROC, et al. Clay nanoparticles for regenerative medicine and biomaterial design: a review of clay bioactivity. Biomaterials. 2018;59:204-214. doi:10.1016/j. biomaterials.2017.12.024

76. Nam PT, Thom NT, Phuong NT, et al. Synthesis, characterization and antimicrobial activity of copper doped hydroxyapatite. Vietnam J Chem. 2018;56(6):672-678. doi:10.1002/vjch.20180 0068

77. Nawang R, Hussein MZ, Matori KA, et al. Physicochemical properties of hydroxyapatite/montmorillonite nanocomposite prepared by powder sintering. Results Phys. 2019;15:102540. doi:10. 1016/j.rinp.2019.102540

78. Nazeer MA, Yilgör E, Yilgör I. Intercalated chitosan/hydroxyapatite nanocomposites: promising materials for bone tissue engineering applications. Carbohydr Polym. 2017;175:38-46. doi:10. 1016/j.carbpol.2017.07.054

79. Nichol T, Callaghan J, Townsend R. The antimicrobial activity and biocompatibility of a controlled gentamicin-releasing single-layer sol-gel coating on hydroxyapatite-coated titanium. Bone Joint J. 2021;103B(3):522-529. doi:10.1302/0301-620X.10 3B3.BJJ-2020-0347.R1

80. O’Connor JP, Kanjilal D, Teitelbaum M. Zinc as a therapeutic agent in bone regeneration. Materials. 2020;13(10):1-22. doi:10. 3390/ma13102211

81. Ofudje EA, Adeogun AI, Idowu MA, et al. Synthesis and characterization of Zn-doped hydroxyapatite: scaffold application, antibacterial and bioactivity studies. Heliyon. 2019;5(5):e01716. doi:10.1016/j.heliyon.2019.e01716

82. Paschalis EP, Dempster DW, Gamsjaeger S, et al. Mineral and organic matrix composition at bone forming surfaces in postmenopausal women with osteoporosis treated with either teriparatide or zoledronic acid. Bone. 2021;145:115848. doi:10.1016/j.bone. 2021.115848

83. Nas P, Abdul RH, Noh H, et al. Synthesis method of hydroxyapatite: a review. Mater Today: Proc. 2019;29:233-239.

84. Qais FA, Shafiq A, Khan HM, et al. Antibacterial effect of silver nanoparticles synthesized using Murraya koenigii (L.) against multidrug-resistant pathogens. Bioinorg Chem Appl. 2019;2019: Article ID 4649506. doi:10.1155/2019/4649506

85. Qi S, He J, Zheng H, et al. Zinc supplementation increased bone mineral density, improves bone histomorphology, and prevents bone loss in diabetic rat. Biol Trace Elem Res. 2020;194 (2):493-501. doi:10.1007/s12011-019-01810-7 
86. Qing C, Pengfei W, Zuoying Y, Xiaoping Y, Danni H, inventor; Univ Beijing Chem Tech., assignee. Porous microsphere cell scaffold with double functions of inhibiting bacteria and promoting bone formation and preparation method thereof. China patent CN 108339152. 2018 July 31.

87. Ratnayake JTB, Mucalo M, Dias GJ. Substituted hydroxyapatites for bone regeneration: a review of current trends. J Biomed Mater Res B Appl Biomater. 2017;105(5):1285-1299. doi:10.1002/jbm. b. 33651

88. Reza G, Hasan M, Soltaniniya M, Massoumi B. In vitro evaluation of sustained ciprofloxacin release from $\kappa$-carrageenan-crosslinked chitosan/hydroxyapatite hydrogel nanocomposites. Int J Biol Macromol. 2019;126:443-453. doi:10.1016/j.ijbiomac.2018.12.240

89. Rodríguez-Vázquez M, Vega-Ruiz $\mathrm{B}$, Ramos-Zúñiga $\mathrm{R}$, et al. Chitosan and its potential use as a scaffold for tissue engineering in regenerative medicine. Biomed Res Int. 2015;2015: Article ID 821279. doi: $10.1155 / 2015 / 821279$

90. Rodríguez J, Mandalunis PM. A review of metal exposure and its effects on bone health. $J$ Toxicol. 2018;2018: Article ID 4854152. doi:10.1155/2018/4854152

91. Sahithi K, Swetha M, Prabaharan M, et al. Synthesis and characterization of nanoscale-hydroxyapatite-copper for antimicrobial activity towards bone tissue engineering applications. $J$ Biomed Nanotechnol. 2010;6(4):333-339. doi:10.1166/jbn.2010.1138

92. Salhotra A, Shah HN, Levi B, et al. Mechanisms of bone development and repair. Nat Rev Mol Cell Biol. 2020;21(11):696-711. doi:10.1038/s41580-020-00279-w

93. Salleh A, Naomi R, Utami N, et al. The potential of silver nanoparticles for antiviral and antibacterial applications: a mechanism of action. Nanomaterials. 2020;10(8):1566. doi:10. 3390/nano10081566

94. Sato C, Yamazaki D, Sato M, et al. Calcium phosphate mineralization in bone tissues directly observed in aqueous liquid by atmospheric SEM (ASEM) without staining: microfluidics crystallization chamber and immuno-EM. Sci Rep. 2019;9:1-13. doi:10.1038/s41598-019-43608-6

95. Shariatinia Z. Pharmaceutical applications of chitosan. Adv Colloid Interface Sci. 2019;263:131-194. doi:10.1016/j.cis.2018.11.008

96. Siddiqi KS, Ur Rahman A, Husen A. Properties of zinc oxide nanoparticles and their activity against microbes. Nanoscale Res Lett. 2018;13(1):1-3. doi:10.1186/s11671-018-2532-3

97. Sirousazar M. Mechanism of gentamicin sulphate release in nanocomposite hydrogel drug delivery systems. J Drug Deliv Sci Technol. 2013;23(6):619-621. doi:10.1016/S1773-2247(13)50094-3

98. Siswanto S, Hikmawati D, Kulsum U, et al. Biocompatibility and osteoconductivity of scaffold porous composite collagen-hydroxyapatite based coral for bone regeneration. Open Chem. 2020;18(1):584-590. doi:10.1515/chem2020-0080

99. Soliman ASM, Fahad AL, Antonio P, Bahabri FS, inventor; Univ King Abdulaziz., assignee. Bone graft with a tannin-hydroxyapatite scaffold and stem cells for bone engineering. United State patent US 20180071433. 2018 Mar 15.

100. Sossa PAF, Giraldo BS, Garcia BCG, et al. Comparative study between natural and synthetic hydroxyapatite: structural, morphological and bioactivity properties. Revista Materia. 2018;23 (4):1-17. doi:10.1590/s1517-707620180004.0551

101. Stanić V, Dimitrijević S, Antić-Stanković J, et al. Synthesis, characterization and antimicrobial activity of copper and zinc-doped hydroxyapatite nanopowders. Appl Surf Sci. 2010;256(20):6083-6089. doi:10.1016/j.apsusc.2010.03.124

102. Stracquadanio S, Musso N, Costantino A, et al. Staphylococcus aureus internalization in osteoblast cells: mechanisms, interactions and biochemical processes. What did we learn from experimental models? Pathogens. 2021;10(2):1-24. doi:10.3390/pathogens10020239
103. Tang S, Tian B, Ke QF, et al. Gentamicin-loaded carbonated hydroxyapatite coatings with hierarchically porous structures: drug delivery properties, bactericidal properties and biocompatibility. $R S C$ Adv. 2014;40(78):41500-41509. doi:10.1039/C4RA05493H

104. Teng S, Shi J, Peng B, et al. (2006). The effect of alginate addition on the structure and morphology of hydroxyapatite/gelatin nanocomposites. Compos Sci Technol. 2006;66(11-12):15 32-1538. doi:10.1016/j.compscitech.2005.11.021

105. Tran TT, Hamid ZA, Cheong KY. A review of mechanical properties of scaffold in tissue engineering: aloe vera composites. $J$ Phys Conf Ser. 2018;1082:012080.

106. Uddin F. Montmorillonite: an introduction to properties and utilization. In: Zoveidavianpoor M, editor. Current Topics in the Utilization of Clay in Industrial and Medical Applications. London, UK: Intech Open; 2018:3-24.

107. Varadavenkatesan T, Vinayagam R, Pai S, et al. Synthesis, biological and environmental applications of hydroxyapatite and its composites with organic and inorganic coatings. Prog Org Coat. 2021;151:85-88. doi:10.1016/j.porgcoat.2020.106056

108. Vega-Vásquez P, Mosier NS, Irudayaraj J. Nanoscale drug delivery systems: from medicine to agriculture. Front Bioeng Biotechnol. 2020;8:1-16. doi:10.3389/fbioe.2020.00079

109. Venkatasubbu GD, Ramasamy S, Ramakrishnan V, et al. Hydroxyapatite-alginate nanocomposite as drug delivery matrix for sustained release of ciprofloxacin. J Biomed Nanotechnol. 2011;7(6):59-67. doi:10.1166/jbn.2011.1350

110. Wang C, Huang W, Zhou Y, et al. 3D printing of bone tissue engineering scaffolds. Bioact Mater. 2020;5(1):82-91. doi:10. 1016/j.bioactmat.2020.01.004

111. Weaver L, Michels HT, Keevil CW. Survival of clostridium difficile on copper and steel: futuristic options for hospital hygiene. J Hosp Infect. 2008;68(2):145-151. doi:10.1016/j.jhin. 2007.11.011

112. Wei S, Ma J, Xu L, et al. Biodegradable materials for bone defect repair. Mil Med Res. 2020;7(54):1-25.

113. Xiliang C, Da N, Qinghua C, Jingjing X, inventor; Univ Kunming Science \& Tech., assignee. Method for preparing bone tissue engineering scaffold material. China patent CN 105963789. 2016 Sept 28.

114. Xin Z, Yuhe Y, inventor; Shenzhen Research Institute The Hong Kong Polytechnic Univ., assignee. Light curing composite for bone tissue engineering and bone tissue engineering bracket based on light curing composite. China patent CN 110898257. 2020 Mar 24.

115. Xing W, Ni L, Huo P, et al. Applied surface science preparation high photocatalytic activity of CdS/halloysite nanotubes (HNTs) nanocomposites with hydrothermal method. Appl Surf Sci. 2012;59:698-704. doi:10.1016/j.apsusc.2012.07.102

116. Yelten-yilmaz A, Yilmaz S. Wet chemical precipitation synthesis of hydroxyapatite (HA) powders. Ceram Int. 2018;44 (8):9703-9710. doi:10.1016/j.ceramint.2018.02.201

117. Yu F, Jiebing Z, Anchun M, inventor; Univ Sichuan., assignee. Application of MXene, bone tissue regeneration guiding material and preparation method thereof. China patent CN 109589450. 2019 Apr 09.

118. Zhang H, Cheng J, Ao Q. Preparation of alginate-based biomaterials and their applications in biomedicine. Mar Drugs. 2021;19 (5):264. doi:10.3390/md19050264

119. Zhang J, Huang D, Liu S, et al. Zirconia toughened hydroxyapatite biocomposite formed by a DLP 3D printing process for potential bone tissue engineering. Mater Sci Eng C. 2019; 105:110054. doi:10.1016/j.msec.2019.110054

120. Zheng J, Wu F, Li H, et al. Preparation of bioactive hydroxyapatite @ halloysite and its effect on MC3T3-E1 osteogenic differentiation of chitosan film. Mater Sci Eng C. 2019;105:110072. doi:10.1016/j.msec.2019.110072 
121. Zhu Y, Zhu R, Ma J, et al. In vitro cell proliferation evaluation of porous nano-zirconia scaffolds with different porosity for bone tissue engineering. Biomed Mater. 2015;10(5):55009. doi:10.10 $88 / 1748-6041 / 10 / 5 / 055009$
122. Zia I, Mirza S, Jolly R, et al. Trigonella foenum graecum seed polysaccharide coupled nano hydroxyapatite-chitosan: a ternary nanocomposite for bone tissue engineering. Int J Biol Macromol. 2019;124:88-101. doi:59

\section{Publish your work in this journal}

The International Journal of Nanomedicine is an international, peerreviewed journal focusing on the application of nanotechnology in diagnostics, therapeutics, and drug delivery systems throughout the biomedical field. This journal is indexed on PubMed Central, MedLine, CAS, SciSearch ${ }^{\mathbb{R}}$, Current Contents ${ }^{\mathbb{R}} /$ Clinical Medicine, $^{2}$
Journal Citation Reports/Science Edition, EMBase, Scopus and the Elsevier Bibliographic databases. The manuscript management system is completely online and includes a very quick and fair peer-review system, which is all easy to use. Visit http://www.dovepress.com/ testimonials.php to read real quotes from published authors. 